\title{
Religiosity and Same-Sex Marriage in the United States and Europe*
}

\author{
David B. Oppenheimer,** Alvaro Oliveira, $\dagger$ and Aaron \\ Blumenthal $\ddagger$
}

\section{INTRODUCTION}

There has been a sea change in marriage equality in recent years, so much so that it is difficult to keep up with all the recent advancements. Twenty years ago, no country in the world and not a single US state had authorized same-sex marriage. Ten years ago, only a small number of countries and states did so. Today, the number of places where same-sex marriage is legal is growing so quickly that by the time this Article is published, it will almost certainly be outof-date.ll

Currently in the United States, thirteen states and the District of Columbia permit same-sex marriage, enabling same-sex couples to enjoy the full and complete benefits of marriage, ${ }^{1}$ although their marriages may not be recognized in some other states. Another seven states provide varying levels of recognition of same-sex relationships (through civil union and domestic partnership laws). ${ }^{2}$ An overlapping thirty-five states have adopted restrictive language defining

\footnotetext{
* Earlier versions of this paper were presented to the University of Paris X (Nanterre)'s comparative law workshop, Rutgers Camden Law School and Temple University's Workshop on European Law, supported by the European Union Center of Excellence, and the Berkeley Comparative AntiDiscrimination Law Virtual Study Group. We are grateful to the participants, and to Russell Robinson, for their comments.

** Clinical Professor of Law, University of California, Berkeley, School of Law.

$\dagger \mathrm{PhD}$ European University Institute, Florence, currently working in an EU institution, but the opinions expressed are his own only.

¥ JD Candidate, University of California, Berkeley, School of Law, Class of 2015.

$\|$ We note that as this Article was going to press, New Jersey legalized same-sex marriage.

1. National Conference of State Legislatures, Same Sex Marriage Laws (Feb. 14, 2013), http://archive.is/txECg (these include the District of Columbia, Massachusetts, Connecticut, Iowa, Vermont, New Hampshire, New York, Maryland, Maine, Washington, Rhode Island, Delaware, Minnesota, and California).

2. National Conference of State Legislatures, Civil Unions \& Domestic Partnership Statutes (updated June 26, 2013), http://archive.is/A80Lt (these include Hawaii, Nevada, Oregon, Illinois, Wisconsin, New Jersey, and Colorado).
} 
marriage as "between a man and a woman" (twenty-nine through state constitutional amendments and an additional six by statute). ${ }^{3}$

Currently in Europe, ten nations permit same-sex marriage. ${ }^{4}$ An additional thirteen nations provide varying levels of recognition of same-sex partnerships. ${ }^{5}$ But ten nations have adopted constitutional bans on same-sex marriage. ${ }^{6}$ As in the United States, the current trend in Europe is towards more marriage equality. Two of the largest and most influential nations in Europe - the United Kingdom and France-have recently legalized same-sex marriage. Yet many other European states are completely resistant to marriage equality, and even in states that embrace it, there are large vocal minorities that express strong opposition. The same-sex marriage legislation in France, for example, sparked large protests, and a greater participation in politics by the Catholic Church than is common in secular France. ${ }^{7}$

Part I of this paper traces the change in law and attitudes in the United States. Part II does the same for Europe. Part III examines the role of the courts in marriage equality. Part IV asks whether we can explain the differences among US and European states by looking at attitudes about secularism and religiosity.

In brief, we recognize that while correlation is not causation, the correlations are dramatic here. In the United States, most of the states that are

3. National Conference of State Legislatures, State Laws Limiting Marriage to Opposite-Sex Couples (updated June 26, 2013), http://archive.is/94ZRM. The following states provide some recognition for same-sex relationships but have passed "defense of marriage" provisions: Hawaii, Nevada, Oregon, Illinois, and Wisconsin (by constitutional amendment).

4. Nine of the countries are Belgium, Denmark, France, Iceland, Netherlands, Norway, Portugal, Spain, and Sweden. Associated Foreign Press, Same-Sex Marriages Gaining Acceptance, Hindustan TIMES (May 18, 2013), http://archive.is/iVIRd. The tenth country is the United Kingdom (England \& Wales). Associated Press, Britain Legalizes Gay Marriage, HufFINGTON POST (July 17, 2013), http://archive.is/3Ru7b.

5. These countries are Andorra, Austria, Croatia, Czech Republic, Finland, Germany, Hungary, Ireland, Liechtenstein, Luxembourg, Slovenia, Switzerland, and the United Kingdom (Scotland \& Northern Ireland). See Current Status Around-the-World (International), MARRIAGE EQUALITY, USA (Sept. 17, 2012), http://web.archive.org/web/20130117184309/http:/www.marriage equality.org/Around\%20the\%20World (there are varying levels of recognized rights for same-sex couples in Austria, Croatia, Czech Republic, Finland, Germany, Hungary, Ireland, Liechtenstein, Luxembourg, Slovenia, and Switzerland); Rainbow Europe Index 2013, ILGA-EuR., http://www.ilgaeurope.org/home/publications/reports_and_other_materials/rainbow_europe (last visited Oct. 20, 2013) (Andorra has registered partnerships); Civil Partnership, EQUALITY NETWORK, http://archive.is/7MBtW (last visited Oct. 20, 2013) (Scotland has civil unions); Guidance on civil partnerships in Northern Ireland, NIDIRECT, http://archive.is/e5eyN (last visited Oct. 20, 2013) (Northern Ireland has civil unions).

6. These countries are Belarus, Bulgaria, Hungary, Latvia, Lithuania, Moldova, Montenegro, Poland, Serbia, and Ukraine. See MARRIAGe EQUALITY USA, supra note 5 (for constitutional samesex marriage bans in Belarus, Bulgaria, Latvia, Lithuania, Moldova, Montenegro, Poland, Serbia, and the Ukraine). See also New Hungarian constitution comes into effect with same-sex marriage ban, PINK NeWs (Jan. 3, 2012), http://archive.is/Qq2dW (for Hungary's constitutional same-sex marriage ban).

7. Bastien Inzaurralde, French Government Unfazed by Massive Anti-Gay Marriage Protest, CHRISTIAN SCIENCE MONITOR (Jan. 14, 2013), http://archive.is/S79a8. 
relatively non-religious or secular now permit same-sex marriage, while most that are highly religious prohibit it. Of the twelve most religious states, all have constitutional bans on same-sex marriage. Of the twelve least religious states, eleven have some recognition of same-sex relationships: eight have same-sex marriage, two have domestic partnerships, and one has civil unions. ${ }^{8}$ The same trend is largely true in Europe. We thus conclude that there is a close correlation between religiosity and support for same-sex marriage and that further research is appropriate to examine whether it is causative.

I.

\section{The ChANGE IN LAW AND AtTitudes IN THE United STATES}

Twenty years ago in the United States, no state permitted same-sex marriage, nor had any legal provision to recognize same-sex relationships. In general, same-sex couples could not visit each other as family in hospitals, or participate in end-of-life decisions, could not be the legal parents of each other's children, and could not have any of the Social Security, insurance, estate tax, income tax, or property tax benefits of marriage.

In the last few years of the twentieth century, things began to change. In 1992, the District of Columbia City Council passed a limited domestic partnership law. In 1997, the Hawaii Supreme Court required the Hawaii legislature to provide certain contract rights to same-sex couples. In 1999, California passed a domestic partnership law. In 2000, the Vermont Supreme Court required the Vermont legislature to authorize either same-sex marriage or civil unions (they chose civil unions).

As we entered the twenty-first century, a small trickle became a mighty river. In 2003, the Massachusetts Supreme Judicial Court required the legislature to allow same-sex marriage (effective mid-2004), holding that limiting marriage to opposite-sex couples is a violation of equal protection and due process under the state constitution. ${ }^{9}$ The Massachusetts decision opened a floodgate. By the end of 2004, there was legal same-sex marriage in Massachusetts, and civil union or domestic partnership laws in Maine, Vermont, Hawaii, the District of Columbia, and California. In 2005, Connecticut joined the list with civil unions by court order. In 2006, New Jersey joined with civil unions by court order. In 2007, the Washington legislature passed a domestic partnership law. In 2008, the Oregon and Maryland legislatures passed domestic partnership laws, New Hampshire's legislature passed a civil union law, and the Connecticut Supreme Court ruled in favor of full same-sex marriage rights. In 2009, the Vermont

8. National Conference of State Legislatures (NCSL), Same Sex Marriage Laws, supra note 1; NCSL, Civil Unions \& Domestic Partnership Statutes, supra note 2; NCSL, State Laws Limiting Marriage to Opposite-Sex Couples, supra note 3; Frank Newport, Mississippi Maintains Hold as Most Religious U.S. State, GALLUP POLITICS (Feb. 13, 2013), http://www.gallup.com/poll/160415/ mississippi-maintains-hold-religious-state.aspx.

9. Goodridge v. Dep't of Pub. Health, 440 Mass. 309, 344 (2003). 
legislature passed a same-sex marriage law, the Iowa Supreme Court ruled that same-sex couples are entitled to full marriage, the Colorado legislature passed limited partnership rights for same-sex couples, and the Nevada and Wisconsin legislatures passed domestic partnership laws. In 2010, the New Hampshire legislature passed a same-sex marriage law. In 2011, the Illinois, Delaware, Rhode Island, and Hawaii legislatures passed civil union laws, while the New York legislature passed a full marriage rights law. In 2012, the Washington and Maryland state legislatures passed same-sex marriage laws (which were upheld by voter referenda in both states) and Maine voters approved a ballot initiative legalizing same-sex marriage. ${ }^{10}$ In March 2013, Colorado passed legislation to allow civil unions. ${ }^{11}$ In May 2013, Rhode Island, Delaware, and Minnesota all legalized same-sex marriage. ${ }^{12}$ And in June 2013, the US Supreme Court's decision in Hollingsworth $v$. Perry resulted in the legalization of same-sex marriage in California. ${ }^{13}$

The procession has not been one way, however. In Iowa, voters removed three of the seven Supreme Court Justices who voted in favor of same-sex marriage, as a result of a well-funded campaign against their re-election. ${ }^{14}$ Approximately three-fourths of the states have passed statutes, referenda, or constitutional amendments prohibiting same-sex marriage. These states include the entire South (Virginia, North Carolina, South Carolina, Georgia, Florida, Mississippi, Alabama, Louisiana, Texas, Arkansas, Oklahoma, Missouri, and Tennessee), most of the Mountain West and Great Plains (Nevada, Arizona, Utah, Idaho, Colorado, Montana, Wyoming, North Dakota, South Dakota, Nebraska, and Kansas), much of the Mid-West (Wisconsin, Michigan, Indiana, Illinois, and Ohio), much of the Middle Atlantic (Pennsylvania, Kentucky, and West Virginia), and four Pacific Coast states (Oregon, Hawaii, Alaska, and California). ${ }^{15}$ The federal Defense of Marriage Act provides that such states those that do not recognize same-sex marriage-need not give full faith and credit to same-sex marriages performed in states that do allow them. ${ }^{16}$ The

10. NCSL, Same Sex Marriage Laws, supra note 1; NCSL, Civil Unions \& Domestic Partnership Statutes, supra note 2.

11. Lynn Bartels, Colorado House passes civil unions, but fans note marriage is equality, THE DENVER Post (Mar. 12, 2013), http://archive.is/B9Ui4.

12. NCSL, Same Sex Marriage Laws, supra note 1.

13. Hollingsworth v. Perry, 133 S. Ct. 2652, 2668 (2013) (dismissing petitioner's appeal for lack of standing and thus upholding the district court's determination that Proposition 8 was unconstitutional); Perry v. Brown, 681 F.3d 1065, 1066-67 (9th Cir. 2012) (staying the district court's holding pending Supreme Court review).

14. David Pitt \& Michael J. Crumb, Iowa Judges Sacked Over Gay Marriage Ruling, HUFFINGTON POST (Nov. 3, 2010), http://archive.is/qNlvY.

15. NCSL, State Laws Limiting Marriage to Opposite-Sex Couples, supra note 3.

16. See 1 U.S.C. $\$ 7$ (2006) (marriage is defined as being between a man and a woman); 28 U.S.C. $§ 1738 C$ (2006) ("No state" need "give effect" to any law (from another state) that legalizes same-sex marriage). 
Supreme Court's recent decision in United States $v$. Windsor does not affect the full faith and credit portion of the Defense of Marriage Act. ${ }^{17}$

Despite the prohibitions by these thirty-five states, public opinion in the United States appears to be shifting rapidly. The 2012 Washington, Maryland, and Maine ballot initiatives are significant because they mark the first time that voters have approved same-sex marriage by popular vote. These initiatives show how US public opinion has changed in recent years. In fact, Maine voters had repealed a same-sex marriage law, passed by their state legislature, only two years prior to the ballot initiative legalizing same-sex marriage. ${ }^{18}$ Prior to the Washington, Maryland, and Maine ballot initiatives, same-sex marriage had lost on previous ballot initiatives in US states thirty-two times. ${ }^{19}$ Many of these initiatives involved state constitutional amendments banning same-sex marriage. Yet, support for such initiatives has eroded over time. Since 2005, the average support for ballot initiatives banning same-sex marriage has decreased by 16 percentage points. ${ }^{20}$ In 2012, Minnesota became the first state to reject a ballot initiative seeking to amend the state constitution to ban same-sex marriage. ${ }^{21}$

The rapid progress towards increased marriage equality reflects a recent and significant shift in public attitudes. In 2003, 58 percent of Americans opposed same-sex marriage and only 33 percent were in favor. ${ }^{22}$ By 2013, opposition had switched to support, with 50 percent of Americans in favor of same-sex marriage and only 43 percent opposed. ${ }^{23}$ A large share of this shift occurred in only the last four years (with support growing from 37 percent in 2009 to 50 percent in 2013). ${ }^{24}$

According to Nate Silver, this shift has led some people to speculate that growth in support for same-sex marriage is now rising at a faster rate than in previous years. ${ }^{25}$ However, according to a regression analysis performed by Silver, the increase in support has actually been relatively constant since about 2004, when the Massachusetts Supreme Court first brought the issue of gay

17. Windsor dealt with whether the federal definition of marriage in 1 U.S.C. $\S 7$ could constitutionally deny federal benefits to same-sex couples who were legally married in a state that allowed such marriages. See United States v. Windsor, 133 S. Ct. 2675, 2692-93 (2013).

18. Michael Falcone, Maine Vote Repeals Gay Marriage Law, Politico (Nov. 4, 2009), http://archive.is/3pVWA.

19. Rachel Weiner, Why does gay marriage keep losing at the ballot box? WASH. POST (May 9, 2012), http://archive.is/3wiJg.

20. History of State Constitutional Marriage Bans, Human Rights CAMPAign (Oct. 12, 2013), http://archive.is/jhhL3.

21. Don Davis, Minnesota becomes first state to reject constitutional gay-marriage ban, HASTINGS STAR GAZETTE (Nov. 7, 2012), http://archive.is/16xJM.

22. Changing Attitudes on Gay Marriage, PEW RESEARCH CTR. (June 2013), http://archive.is/AJzmA.

23. $I d$.

24. $I d$.

25. Nate Silver, How Opinion on Same-Sex Marriage is Changing, and What it Means, N.Y. TIMES (Mar. 26, 2012), http://archive.is/I4Rr8. 
marriage to the fore by becoming the first state to legalize same-sex marriage. ${ }^{26}$ According to Silver's calculations, same-sex marriage support has risen at a rate of about 2 percentage points a year since that time. ${ }^{27}$

The upward shift in support is consistent across all age groups. Today, the silent generation (born 1928-1945) is 8 percentage points more supportive of same-sex marriage than it was in 2003; baby boomers (born 1946-1964) are 6 percentage points more supportive; generation $X$ (born 1965-1980) is 8 percentage points more supportive, and millennials (born 1981 and after) are 19 percentage points more supportive. ${ }^{28}$ However, there are huge variations between generations, with millennials more than twice as supportive of samesex marriage as their grandparents..$^{29}$ According to Nate Silver, about half of the increase in support for same-sex marriage is due to generational turnover and about half is due to changes in attitudes within generations..$^{30}$

Some of the recent shift in public attitudes likely has to do with the decreased stigma of homosexuality. A greater number of Americans are likely to personally know someone who identifies as homosexual. In 2009, 49 percent of Americans responding to a poll answered that they knew a close friend or family member who was gay or lesbian, whereas by 2012 , that number had increased to 60 percent. ${ }^{31}$ Of the people who have changed their minds about same-sex marriage in the last 10 years, 32 percent said it was because they know someone who was homosexual. ${ }^{32}$ Not only is homosexuality more pertinent on a personal level to Americans, but it has become more prominent on the national stage. In November 2012, Wisconsin became the first state to elect an openly gay Senator. ${ }^{33}$ President Obama also recently became the first president to openly support gay marriage, even going so far as to incorporate marriage equality into his inaugural address and to file an amicus brief to the Supreme Court urging it to overturn the Defense of Marriage Act. $^{34}$ The President stated at the

26. Id.

27. Id.

28. Growing Support for Gay Marriage: Changed Minds and Changing Demographics, PEW RESEARCH CTR. (Mar. 20, 2013), http://archive.is/YKcxM. Millennial support for same-sex marriage increased from 51 percent in 2009 to 70 percent in 2013; generation X support increased from 41 percent to 49 percent; baby boomer support increased from 32 percent to 38 percent; silent generation support increased from 23 percent to 31 percent.

29. Seventy percent of millennials support same-sex marriage, compared to 31 percent of the silent generation.

30. Silver, supra note 25.

31. CNN, CNN/ORC Poll (May 29, 2012), http://i2.cdn.turner.com/cnn/2012/images/06/06/ rel5e.pdf.

32. PEW RESEARCH CTR., supra note 28.

33. Emanuella Grinberg, Wisconsin's Tammy Baldwin is First Openly Gay Person Elected to Senate, CNN (Nov. 7, 2012), http://www.cnn.com/2012/11/07/politics/wisconsin-tammy-baldwinsenate.

34. Brett LoGiurato, There's Been an Unprecedented Shift in Attitudes About Gay Marriage, BUS. INSIDER (Feb. 24, 2013), http://www.businessinsider.com/polls-obama-gay-marriage-brief- 
inauguration for his second term, "Our journey is not complete until our gay brothers and sisters are treated like anyone else under the law - for if we are truly created equal, then surely the love we commit to one another must be equal as well." ${ }^{35}$ Public attitudes and discourse have changed dramatically in the United States since 2008 when a slightly younger Senator Obama said during his 2008 presidential campaign, "I believe marriage is between a man and a woman. I am not in favor of gay marriage." 36

Perhaps decreased stigma and increased national attention have contributed to the recent increase in support for gay marriage. But what explains the more persistent differences in attitude, such as between the silent generation and millennials or between Southern states and Western states (where ballot initiatives to ban gay marriage passed with an average of 75 percent of the vote in the former, but only 58 percent of the vote in the latter) $?^{37}$ One of the most likely culprits to explain these fundamental attitudinal differences is religiosity, as discussed in Part IV.

These are important questions to ask in an age where public opinion is increasingly important to marriage equality. Ballot initiatives have been used to overturn same-sex marriage court decisions, such as in California in 2008. ${ }^{38}$ Ballot initiatives have been used to repeal state legislation legalizing same-sex marriage, such as in Maine in 2010..$^{39}$ And ballot initiatives are the main source of state constitutional amendments to ban same-sex marriage. Increasingly, same-sex marriage law in the United States has tracked public opinion. Nate Silver projects that if current trends continue, by 2016, a majority of voters in 32 states will support same-sex marriage (up from 21 states in 2012), and by 2020 , a majority of voters in 44 states will do so..$^{40}$

II.

Changes in LAW AND AtTitudes in EURope

\section{A. The Changing Legal Landscape}

Unlike in the United States, marriage equality in Europe has come exclusively from legislatures, and not from the judiciary or public referenda. In

prop-8-supreme-court-2013-2.

35. Brett LoGiurto, Obama Mentions Gay Rights For The First Time Ever In An Inaugural Address, BuS. INSIDER (Jan. 21, 2013), http://www.businessinsider.com/obama-gay-rightsinaugural-speech-2013-1.

36. Mackenzie Weinger, Evolve: Obama gay marriage quotes, POLITICO (May 9, 2012), http://www.politico.com/news/stories/0512/76109_Page2.html.

37. Human Rights CAMPAign, supra note 20.

38. See Pete Williams \& Erin McClam, Prop 8 ruling explained: Why gay marriage will resume in California, NBC News (June 26, 2013), http://archive.is/COxP7 (Proposition 8 overturned the California Supreme Court decision which had initially legalized same-sex marriage).

39. See Falcone, supra note 18.

40. Silver, supra note 25. 
the twentieth century, Europe broke major ground in providing rights for samesex couples, but progress was initially slow. In 1989, Denmark became the first country in the world to grant any official rights to same-sex couples by providing that same-sex individuals could enter civil unions. ${ }^{41}$ Ten years later, in 1999, France recognized civil unions-called civil solidarity pacts (or "PACS") - for all couples, regardless of sex. ${ }^{42}$

As in the United States, progress accelerated in the first decade of the twenty-first century, and appears to be developing even more rapidly in the second decade. In 2001, the Netherlands became the first country in the world to allow same-sex marriage, and in the same year, Germany created registered partnerships for same-sex couples. ${ }^{43}$ In 2002, Finland created registered partnerships. In 2003, Belgium allowed same-sex marriage, and Croatia extended limited unregistered cohabitation rights to same-sex couples. ${ }^{44}$ In 2004, Luxembourg recognized registered partnerships.45 In 2005, Spain extended marriage to same-sex couples, the United Kingdom passed a registered partnership law, and Andorra created civil unions. ${ }^{46}$ In 2006, Slovenia and the Czech Republic passed registered partnership laws, as did Switzerland in $2007 .{ }^{47}$ In 2009, Norway and Sweden extended marriage to same-sex couples, and Hungary effectuated a registered partnership law. ${ }^{48} 2010$ saw Iceland and Portugal legalizing same-sex marriage and Austria creating registered partnerships. ${ }^{49}$ In 2011, Ireland and Lichtenstein recognized same-sex registered partnerships. ${ }^{50}$ Finally, in 2012, twenty-three years after becoming the first nation to recognize civil unions, Denmark legalized same-sex marriage. ${ }^{51}$

Furthermore, 2013 is becoming an exciting year for marriage equality in Europe. The United Kingdom and France, two of the most influential states in

41. MarRiage EQUALITY USA, supra note 5.

42. Catherine Raissiguier, The Sexual and Radical Politics of Civil Unions in France, 83 RADICAL HIST. REV. 73 (2002).

43. MARRIAGE EQUALITY USA, supra note 5.

44. Id.

45. Id.

46. See id. (for information on Spain and the United Kingdom); Study on Homophobia, Transphobia and Discrimination on Grounds of Sexual Orientation and Gender Identity Sociological Report: Andorra, COWI, 3, http://www .coe.int/t/Commissioner/Source/LGBT/Andorra Sociological_E.pdf (last visited Oct. 20, 2013) (Andorra first recognized civil unions in March 2005).

47. See MARriage EQuality USA, supra note 5 (for information on Slovenia and the Czech Republic); Switzerland, GLBTQ (2008), http://archive.is/pDYVv (the Swiss registered partnership law went into effect in 2007).

48. MARRIAGE EQUALITY USA, supra note 5.

49. Id.

50. See id. (for information on Lichtenstein); Becoming an Irish Citizen Through Marriage or Civil Partnership, CitiZENS INFO. BD. OF IRELAND, http://archive.is/3IkdQ (last visited Oct. 20 , 2013) (for information on Ireland).

51. MARRIAGE EQUALITY USA, supra note 5. 
Europe, are making waves for same-sex marriage. On May 18, President Hollande signed France's "marriage for all" act into law. ${ }^{52}$ And on July 15, the British Parliament passed a bill to legalize same-sex marriage in England and Wales. ${ }^{53}$ The first same-sex marriages will begin in summer $2014 .{ }^{54}$ The British Parliament, however, does not have jurisdiction to dictate marriage policies for the rest of the United Kingdom (Scotland and Northern Ireland). ${ }^{55}$ Scotland is attempting to fast-track a same-sex marriage bill through its parliament. ${ }^{56}$ The legislation enjoys wide cross-party support and is slated to pass by March $2014 .{ }^{57}$

While these developments may appear to be cause for celebration for supporters of same-sex marriage, not every glimmer of progress solidifies into an actual recognition of rights. For example, Slovenia's legislature passed a new family code in 2011 that would have provided completely equal rights to samesex couples in domestic partnerships, but the proposal was rejected by a referendum of Slovenia's voters in 2012.58 Luxembourg had a parliamentary proposal in 2010 to legalize same-sex marriage, but the bill has gone nowhere..$^{59}$ A Finnish same-sex marriage proposal in 2013 recently died in committee, on a narrow vote. ${ }^{60}$

In addition, the push for marriage equality in Germany has been met with resistance from the legislature's conservative wing. Initially, there were some indications in Germany that Chancellor Angela Merkel might reverse course in her party's firm stance against marriage equality. In 2012, Germany's highest court (the Federal Constitutional Court) ruled that registered partners must be granted the same tax exemptions in property transfers that are granted to married couples. ${ }^{61}$ This decision prompted thirteen members of Merkel's party-the

52. Steven Erlanger, Hollande Signs French Gay Marriage Law, N.Y. TimES, May 18, 2013, at $\mathrm{A} 8$.

53. Supra note 4, Associated Foreign Press.

54. Id.

55. FAQ: Why will same-sex marriage be legal only in England and Wales? And other questions, PINK NEWS (July 20, 2013), http://archive.is/eqA1K.

56. Same-sex marriage Bill to be fast-tracked through Holyrood, THE HERALD SCOTLAND (Aug. 31, 2013), http://archive.is/qWw94.

57. Id. Northern Ireland, however, is unlikely to follow suit. PINK NEWS, supra note 55.

58. J.C. von Krempach, Slovenia Says No to Same-Sex Marriage, TuRTLE BAY AND BEYOND (Mar. 26, 2012), http://archive.is/h0Rjc.

59. See Timothy Kincaid, Luxembourg takes next step towards marriage equality, Box TURTLE BULLETIN (Aug. 14, 2010), http://archive.is/eIC0o (stating that the Luxembourg legislation had introduced same-sex marriage legislation); Adoption et mariage gay devront attendre, L'ESSENTIEL ONLINE (July 25, 2013), http://archive.is/Oa7nY (the bill never became law and Luxembourg has still subsequently been unable to pass same-sex marriage legislation) (Fr.).

60. Parliamentary committee narrowly blocks same-sex marriage, YLE UUTISET (Feb. 27, 2013), http://archive.is/IGQJf (Fin.).

61. Fred Pleitgen, Germany's High Court Expands Gay Rights, CNN (Aug. 9, 2012), http://archive.is/XAPXj. 
Christian Democratic Union (or CDU) - to call for income tax equality for registered same-sex partners. ${ }^{62}$ The thirteen members wrote that it was unacceptable that Merkel's government "again has to be ordered by the constitutional court to abolish inequalities." ${ }^{63}$ Then in 2013, the Constitutional Court ruled that same-sex partners have the right to adopt their partner's children and ordered parliament to change the law to so-reflect by the end of June. ${ }^{64}$ Also, the court's president openly hinted that he and his fellow justices would likely take further steps towards granting same-sex couples additional rights, such as requiring that same-sex partners be treated the same as married couples for income taxation. ${ }^{65}$ In response to the court's ruling, Volker Krauder, the head of the CDU, demanded that his party change its stance on the rights of same-sex couples, restating the refrain that the Conservatives should be embarrassed that they must be forced, once again, by the court to grant equal rights to same-sex couples. ${ }^{66}$ Pressure for change continued to build as other prominent members of Merkel's party, including her Finance Minister, pushed the CDU to change its stance on gay rights, but Merkel ultimately had to bow to pressure from the more conservative elements of her party and abandon the push to change the party platform. ${ }^{67}$ Thus, for the moment, further progress in Germany towards marriage equality must come from the Constitutional Court, not the legislature. However, the next round of elections in October 2013 may have changed the situation, if the new governmental coalition-which has not yet formed-were to include the SPD social-democratic party. ${ }^{68}$

Finally, parts of Europe remain intransigently opposed to marriage equality. Most of Eastern Europe does not provide any official recognition of same-sex relationships and many Eastern European states also have constitutional bans on same-sex marriage. Of the South-East states, four do not recognize same-sex relationships (Albania, Bosnia \& Herzegovina, Macedonia, Slovakia), six have constitutional bans on same-sex marriage (Bulgaria, Hungary, Montenegro, Poland, Serbia, Ukraine), one country recognizes limited rights for same-sex couples (Croatia recognizes unregistered cohabitation), and three countries recognize full partnerships (the Czech Republic, Hungary, Slovenia). ${ }^{69}$ Of the Far Eastern European states, six countries do not recognize

62. Id.

63. Id.

64. Charles Hawley, Campaign Conundrum: Merkel Walks a Fine Line on Gay Rights, DER SPIEGEL (Mar. 5, 2013), http://www.spiegel.de/international/germany/chancellor-merkel-walks-afine-line-on-gay-marriage-a-887015.html (Ger.).

65. Id.

66. Id.

67. Laura Stevens, Merkel Scraps Gay Rights Push, WALL St. J., Mar. 5, 2013, at A10.

68. See Holger Hansen \& Alexandra Hudson, Germany's SPD backs coalition talks with Merkel, sets terms, REUTERS (Oct. 20, 2013), http://archive.is/Q8Q9k.

69. See MARRIAGe EQUALITY USA, supra note 5 (for information on all of the forgoing, except Hungary's constitutional same-sex marriage ban); PINK NEWS, supra note 6 (for information 
same-sex relationships (Armenia, Azerbaijan, Georgia, Kyrgyzstan, Russia, Tajikistan), one country has a constitutional ban (Belarus), and one country still outlaws same-sex sexual activity (Uzbekistan). ${ }^{70}$ Of the Baltic states, one does not recognize same-sex unions (Estonia) and two have constitutional bans on same-sex marriage (Latvia, Lithuania). ${ }^{71}$ Lastly, of the Romano-Hellenic and Southern states, seven provide no recognition (Cyprus, Greece, Italy, Monaco, Romania, Turkey, Vatican City) and one has a constitutional ban on same-sex marriage (Moldova). ${ }^{72}$ In sum, only four Eastern European nations provide any recognition to same-sex couples: Croatia, the Czech Republic, Hungary, and Slovenia. ${ }^{73}$

\section{B. Public Attitudes in Europe Towards Same-Sex Marriage}

The recent advance in same-sex marriage rights in Europe appears to be driven by strong public support, such as in France and the UK. In France, public support for same-sex marriage grew from 48 percent in 1996 to 55 percent in 2003 to 65 percent in $2012 .{ }^{74}$ In the UK, 71 percent of Britons support their government's recent efforts to extend civil marriage to same-sex couples. ${ }^{75}$

In the European Union generally, the countries with the most public support of marriage equality have either legalized same-sex marriage or have provided official recognition of same-sex relationships in the form of registered partnerships. In the last Eurobarometer survey to address the issue in 2006, an average of 44 percent of EU citizens supported allowing same-sex marriage across the EU. ${ }^{76}$ On average, in EU countries that have legalized same-sex marriage, there was a rate of 61.5 percent public support as of 2006 for EU-wide same-sex marriage (82 percent in the Netherlands, 71 percent in Sweden, 69

on Hungary's same-sex marriage ban).

70. See MARRIAge EQUALity USA, supra note 5 (for information on all of the forgoing countries, except Tajikistan, Kyrgyzstan, and Uzbekistan); Daniel Ottosson, State Sponsored Homophobia, ILGA, 41 (Apr. 2007), http://ilga.org/historic/Statehomophobia/State_sponsored_ homophobia_ILGA_07.pdf (intercourse between two males is illegal in Uzbekistan); Tajikistan: Law, ILGA-ASIA, http://oi40.tinypic.com/o0qkaw.jpg (last visited Oct. 20, 2013) (Tajikistan has no recognition of same sex relationships); Krygyzstan: Law, ILGA-AsIA, (last visited Oct. 20, 2013), http://oi39.tinypic.com/20at0gh.jpg (Kyrgyzstan has no recognition of same-sex relationships).

71. MARRIAGE EQUALITY USA, supra note 5.

72. Id.

73. See id.

74. Les Français et les droits des couples homosexuels, IFOP (May 10, 2004), http://web.archive.org/web/20040826064139/http://www.ifop.com/europe/sondages/OPINIONF/droi tshomo.asp (Fr.); Xavier Héraud, Sondage: 65\% des Français-e-s sontfavorables à l'ouverture du mariage pour les homos, YAGG (Aug. 15, 2012), http://archive.is/tDHFG (Fr.).

75. YouGov Survey Results, YouGov (Nov. 25-Dec. 5, 2011), at*5, http://cdn.yougov.com/ cumulus_uploads/document/fi1b20gjes/12\%200612\%20Stonewall\%20attiude\%20tables\%20rebased \%20-\%20for\%20website\%20v2.pdf.

76. 2.4 Attitudes Towards Homosexuality, EUR. COMM'N (2012): EUROBAROMETER 66.3 (Nov.-Dec. 2006), http://www.ilga-europe.org/home/news/latest_news/eu_attitudes_towards_ same_sex_marriage_adoption_significantly_vary. 
percent in Denmark, 62 percent in Belgium, 56 percent in Spain, and 29 percent in Portugal). ${ }^{77}$ Portugal remains an interesting outlier in that it legalized samesex marriage in spite of low public support. In countries that have registered partnership laws, there was an average rate of public support as of 2006 of 46.9 percent for EU-wide same-sex marriage (58 percent in Luxembourg, 52 percent in Germany, 52 percent in the Czech Republic, 49 percent in Austria, 48 percent in France, 46 percent in the UK, 45 percent in Finland, 41 percent in Ireland, and 31 percent in Slovenia). ${ }^{78}$ Slovenia is an intriguing outlier, having passed a domestic partnership law in spite of low public support for marriage equality. In countries that do not recognize same-sex relationships, there was an average rate of public support for same-sex marriage as of 2006 of 19.7 percent (31 percent in Italy, 21 percent in Estonia, 19 percent in Slovakia, 18 percent in Malta, 15 percent in Greece, and 14 percent in Cyprus). ${ }^{79}$ Lastly, in countries with constitutional bans on same-sex marriage, there was an average rate of public support as of 2006 of 16 percent for EU-wide same-sex marriage (18 percent in Hungary, 17 percent in Lithuania, 17 percent in Poland, and 12 percent in Latvia).

Like in the United States, millennials globally are far more supportive of same-sex marriage than their parents or grandparents. Eighty-three percent of millennials in the Netherlands, 81 percent in Spain, 81 percent in Sweden, 78 percent in Germany, 74 percent in Italy, 74 percent in the UK, 71 percent in France, 66 percent in Greece, and 54 percent in Poland support same-sex marriage.${ }^{80}$ Compared to the Eurobarometer survey results, ${ }^{81}$ it appears that only in the Netherlands is millennial support for same-sex marriage roughly equivalent to the national average. Millennials in Spain and Germany are much more supportive than the national average, and millennials in Greece and Poland appear to be substantially more supportive than the national average. ${ }^{82}$

What explains higher support for same-sex marriage among millennials? And why is this effect not seen in the Netherlands? Furthermore, why have Portugal and Slovenia passed marriage equality laws in spite of low public support on the issue? These questions will be addressed in Part IV.

77. Id.

78. Id.

79. Id.

80. Christian Kurtz, Globally, Millennials Show Support for Same-Sex Marriage, VIACOM INT'L MEDIA NETWORKS (Feb. 12, 2013), http://archive.is/GCWC6.

81. Although the Eurobarometer was taken several years before the Millennial poll, the gaps in support between Millennials and the national averages are still quite substantial, even assuming the national averages grew at roughly 2 percent a year, as in the United States.

82. See Kurtz, supra note 80 (for millennial statistics); See also EUROBAROMETER, 2.4 Attitudes Towards Homosexuality (2006), supra note 76 (for national averages). 
III.

The Role of the Courts in Crafting Same-Sex Marriage Policy

\section{A. The United States}

The legitimacy of prohibiting same-sex marriage has been under review by the highest courts in the United States and in Europe. In two recent decisions this June, the US Supreme Court held that the Defense of Marriage Act's restrictive definition of marriage was unconstitutional and allowed the judicial striking down of California's Proposition 8 to stand. ${ }^{83}$ In Europe, the European Court of Human Rights decided in 2012 that Austria could lawfully refuse to authorize same-sex marriage without violating the European Convention on Human Rights. ${ }^{84}$

The US Defense of Marriage Act (DOMA), passed in 1996, defines marriage as "only a legal union between one man and one woman" in regards to all federal regulations and legislation, which includes, inter alia, receiving federal benefits to which spouses are entitled (such as Social Security) and federal tax credits, exemptions, and deductions. ${ }^{85}$ In addition, DOMA provides that states that do not recognize same-sex marriage need not give full faith and credit to same-sex marriages attained in states where they are legal. ${ }^{86}$ In United States v. Windsor, the United States Supreme Court upheld the Second Circuit's decision that DOMA's restrictive definition of marriage violates equal protection under the Fifth Amendment. ${ }^{87}$ The Second Circuit held that homosexuals are a "quasi-suspect class," and therefore, laws that single them out are subject to intermediate scrutiny. DOMA did not survive such scrutiny.${ }^{88}$ The Supreme Court held that DOMA's definition of marriage violated both due process and equal protection, but the Court did not apply intermediate scrutiny to laws singling out homosexuals and attempted to limit its holding by continuing to allow states (but not the federal government) to adopt their own definitions of marriage. ${ }^{89}$ Justice Scalia in his dissent noted that Justice Kennedy's majority opinion in Windsor seems to punt the issue of the

83. Williams \& McClam, supra note 38.

84. See Schalk \& Kopf v. Austria, App. No. 30141/04, Eur. Ct. H.R. (June 24, 2010), at 14, available at http://www.menschenrechte.ac.at/uploads/media/Schalk_und_Kopf_gg_OEsterreich_ Urteil_01.pdf.

85. 1 U.S.C. $\$ 7$.

86. 28 U.S.C. $\$ 1738$ C.

87. Windsor v. United States, 699 F.3d 169, 188 (2d Cir. 2012), cert. granted, 133 S. Ct. 786 (2012), and aff'd.

88. Id. at 185,188 .

89. United States v. Windsor, 133 S. Ct. 2675, 2693 (“[DOMA] violates basic due process and equal protection principles ..."). Justice Kennedy, in fact, seems to apply a balancing test that defies classification on the scrutiny scale, stating that a legitimate government purpose must outweigh illegitimate purposes, such as those based on animus. Id. at 2698 ("The federal statute is invalid, for no legitimate purpose overcomes the purpose and effect to disparage and to injure ...”). 
constitutionality of state defense of marriage provisions (under the Fourteenth Amendment) further on down the line, with Justice Scalia speculating that this issue might be decided during the Supreme Court's next term..$^{90}$ Windsor provides little guidance on how the Supreme Court might rule on the constitutionality of state DOMA provisions, since Justice Kennedy's holding rests in part on finding a violation of federalism principles, leaving the question of whether Windsor's holding would also apply to state DOMA provisions unanswered. ${ }^{91}$ Time will tell (perhaps soon) how this issue will be decided by the Court.

The 2013 California Proposition 8 Supreme Court case, Hollingsworth $v$. Perry, was decided on much narrower grounds. In 2008, the California Supreme Court held that marriage was a fundamental right under the state constitution and that denying this right on the basis of sexual orientation violated equal protection under the California Constitution. ${ }^{92}$ The California Supreme Court ruling legalized same-sex marriage in California. However, later that same year, California voters passed Proposition 8, which amended the state constitution to add the following language: "[o]nly marriage between a man and a woman is valid or recognized in California." 93 Thus, Proposition 8 effectively overruled the California Supreme Court's decision by amending the state constitution to prohibit same-sex marriage. Same-sex marriage proponents challenged Proposition 8 in the United States District Court for the Northern District of California, which held in June 2010 that Proposition 8 was unconstitutional. ${ }^{94}$ After the district court's decision, the State of California decided that it would no longer defend Proposition 8 and would not seek an appeal. ${ }^{95}$ However, supporters of Proposition 8, who had intervened in the original suit, appealed the district court's decision to the Ninth Circuit. ${ }^{96}$ The Ninth Circuit held that the intervenors had standing to defend Proposition 8 and affirmed the district court's holding on the merits. ${ }^{97}$ The Ninth Circuit then granted a stay of its holding until the Supreme Court had a chance to review the case; same-sex marriages could therefore not resume in California until the Supreme Court issued its holding. ${ }^{98}$ The Supreme Court held that the intervenors did not have standing to defend the

90. Id. at 2705 (Scalia, J., dissenting).

91. See id. at 2705-07 (stating that Kennedy's holding borrows a bit from due process, a bit from equal protection, and a bit from federalism); Windsor v. United States, 133 S. Ct. 2675, 269697 (Roberts, J., dissenting) (clarifying that the majority opinion rests its holding on federalism grounds and is thus not applicable to state DOMA provisions).

92. In re Marriage Cases, 43 Cal. 4th 757, 843 (2008).

93. California Voter Guide (2008), available at http://voterguide.sos.ca.gov/past/2008/ general/text-proposed-laws/text-of-proposed-laws.pdf\#prop8.

94. Perry v. Schwarzenegger, 704 F. Supp. 2d 921, 1003 (N.D. Cal. 2010).

95. Hollingsworth, $133 \mathrm{~S}$. Ct. at 2660.

96. Id.

97. Id. at 4-5.

98. Perry v. Brown, 681 F.3d at 1066. 
law in federal court, only the State of California could do so, and thus the intervenors should not have been allowed to appeal the district court's holding to the Ninth Circuit. ${ }^{99}$ Thus, the district court's holding - that Proposition 8 was unconstitutional-still stands. ${ }^{100}$ As a result, the Ninth Circuit's stay expired and same-sex marriages, which were legal pre-Proposition 8 , have resumed in California.

Although the Supreme Court declined to decide Hollingsworth v. Perry on the merits, the story in California is similar to that of Colorado in Romer $v$. Evans, in which a number of municipalities in Colorado passed ordinances banning discrimination based on sexual orientation in housing, employment, and education. ${ }^{101}$ Colorado voters responded by passing Amendment 2, amending the state constitution to preclude any legislation from protecting people on the basis of sexual orientation. ${ }^{102}$ The Supreme Court held in Romer that Amendment 2 was unconstitutional under the Fourteenth Amendment. Similarly, in its Proposition 8 holding, the Ninth Circuit noted that Romer forbids states from taking away a right that has already been granted to homosexuals, whether the right is granted through city ordinance or court decision. ${ }^{103}$ Given his dissent on the standing issue in Hollingsworth, Justice Kennedy appeared ready to decide Hollingsworth on the merits, ${ }^{104}$ so that if the Supreme Court were once again faced with the question in Hollingsworthwhether a state can take away a right that has already been granted to homosexuals - it seems likely that Justice Kennedy would vote to decide the case similarly to Romer. The days when ballot initiatives could reverse forward progress on same-sex marriage may be over.

\section{B. Europe}

In Europe, the European Court of Human Rights (ECtHR) ruled in Schalk and Kopf v. Austria that member states of the Council of Europe are not compelled to authorize same-sex marriages under the European Convention on Human Rights. ${ }^{105}$ In 2002, Mr. Schalk and Mr. Kopf requested a marriage permit in Austria, but state authorities refused on the grounds that same-sex

\footnotetext{
99. Hollingsworth, slip op. at 17.

100. Id.

101. Romer v. Evans, 517 U.S. 620, 620 (1996).

102. Id.

103. Perry v. Brown, 671 F.3d 1052, 1076 (9th Cir. 2012) cert. granted, 133 S. Ct. 786 (2012).

104. The majority in Hollingsworth declined to reach the merits (of whether the Equal Protection Clause prohibits states from denying marriage equality to same-sex couples), holding instead that the petitioners (who were the proponents of Proposition 8) lacked standing to appeal the district court's decision. See 133 S. Ct. at 2659. Justice Kennedy disagreed in his dissent, stating that when a state's government officials refuse to defend a ballot initiative in court, the proponents of the initiative should be granted standing to defend the initiative. See id. at 2668 (Kennedy, J., dissenting). Therefore, Justice Kennedy would have decided the case on the merits. See id.

105. Schalk and Kopf v. Austria, supra note 84.
} 
marriage was not permitted in Austria. ${ }^{106}$ Schalk and Kopf filed suit but lost in all of Austria's courts, so they appealed to the European Court of Human Rights. The ECtHR stated that same-sex couples fell within Article 8 of the European Convention on Human Rights, which provides that, "Everyone has the right to respect for his private and family life." 107 The court held that "the relationship of the applicants, a cohabiting same-sex couple living in a stable de facto partnership, falls within the notion of 'family life,' just as the relationship of a different-sex couple in the same situation would." ${ }^{108}$ Because same-sex couples enjoy protection of their family life under Article 8, the court held that Article 14 (which enhances other recognized rights) applied to them as well. ${ }^{109}$ Article 14 states, "The enjoyment of the rights and freedoms set forth in this Convention [such as the right to respect for one's family life] shall be secured without discrimination on any ground." 110 The ECtHR applies a similar standard under Article 14 as the US Supreme Court does when evaluating equal protection claims under the 14th Amendment, testing whether the state has a legitimate interest in treating one group differently from another and whether the means employed are sufficiently related to this goal:

The Court has established in its case-law that in order for an issue to arise under Article 14 there must be a difference in treatment of persons in relevantly similar situations. Such a difference of treatment is discriminatory if it has no objective and reasonable justification; in other words, if it does not pursue a legitimate aim or if there is not a reasonable relationship of proportionality between the means employed and the aim sought to be realised. The Contracting States enjoy a margin of appreciation in assessing whether and to what extent differences in otherwise similar situations justify a difference in treatment. ${ }^{111}$

While the ECtHR appears to subject discrimination against homosexuals to what would be called in the United States "heightened scrutiny" ("like differences based on sex, differences based on sexual orientation require particularly serious reasons by way of justification"), the effect of the "wide margin of appreciation" that it affords states in crafting "economic and social strategy" is to make the standard of review closer to the US "rational basis" test."12 The ECtHR ultimately held that the decisions of whether to recognize same-sex relationships and to what extent to recognize these relationships fall within each state's "margin of appreciation." 113

If the ECtHR had held that the Convention required all Council of Europe states to recognize the right to same-sex marriage, it would have applied to

\footnotetext{
106. Id. at 2 .

107. Id. at 15 .

108. Id. at 21 .

109. Id. at 20 .

110. Id. at 15 .

111. Id.

112. See id.

113. Id. at 23 .
} 
several countries in which there is very strong opposition to same-sex marriage, such as Russia and Turkey. ${ }^{114}$ And it would have applied to countries that have constitutional bans on same-sex marriage, such Poland, Lithuania, Latvia, and Ukraine. Some have speculated that the court may fear that some European countries may feel so strongly about same-sex marriage that they would have been willing to withdraw from the Council of Europe in order to avoid same-sex marriage being imposed upon them.

However, the court seems to be walking on a tight rope, balancing between the need to apply the European Convention on Human Rights' equal treatment provisions to homosexuals with the need to avoid the political third rail of full same-sex marriage legalization. Under the Convention, the court has been granting more and more rights to gay people, particularly in the last decade. For example, in the July 2002 case of Goodwin v. United Kingdom, the court found that the United Kingdom violated Articles 8 (right to private and family life) and 12 (right to marry) of the Convention on Human Rights because the UK did not allow a transgender individual to get married. ${ }^{115}$ Ms. Goodwin was a postoperative male to female transgender individual who presented herself to society as a female, but for legal purposes continued to be recognized by the UK as male. ${ }^{116}$ In other cases, the court upheld the equal treatment of gay people such as in cases of the attribution of child custody and the right to adopt children. ${ }^{117}$ However, in Schalk and Kopf, it failed to recognize the right of same sex couples to get married. ${ }^{118} \mathrm{We}$ might say that the court has an "everything but marriage syndrome."

How long the European Court of Human Rights can keep this increasingly contradictory dynamic - that of granting more and more rights to gay people under the Convention's requirement of equal treatment, while stopping short of recognizing equal marriage rights - remains to be seen.

As a result of Schalk, same-sex marriage decisions in Europe must be decided at the national level. Likewise in the United States, given the Supreme Court's holdings in Windsor and Perry, we should expect the legal effort to secure equality rights in marriage to proceed on a state-by-state basis. ${ }^{119}$

114. This staunch opposition is not surprising, given that Turkey is the most religious country in Europe (see Part IV), and Turkey's population is 99.8\% Muslim. CIA World Factbook Turkey (2008 est.) (updated Mar. 26, 2013), https://www.cia.gov/library/publications/the-worldfactbook/geos/tu.html.

115. Goodwin v. United Kingdom, App. No. 28957/95, Eur. Ct. H.R. (July 11, 2002), at 9g 93, 104, available at http://www.bailii.org/eu/cases/ECHR/2002/588.html.

116. Id. at IJ 12-13, 21-22.

117. See X v. Austria, Application no. 19010/07, Eur. Ct. H.R 057 (2013).

118. Schalk and Kopf v. Austria, supra note 84, at 14.

119. Although litigation efforts at the federal level (based on the 14th Amendment) will continue to play a role in the fight for marriage equality, the Supreme Court has expressed an unwillingness in Windsor and Perry to legalize marriage in states that have never done so. 
To determine what factors may speed or impede state-level efforts to effectuate marriage equality, we turn to the question of what causes different levels of support for same-sex marriage among different US and European states.

IV.

\section{POSSIBLE EXPLANATIONS FOR DIFFERENTIAL SUPPORT FOR SAME-SEX MARRIAGE IN EUROPE AND THE UNITED STATES}

\section{A. United States}

\section{Religion in General}

We propose that religiosity may be a major driver of public opposition to recognizing same-sex relationships. In the twelve most religious US states (as measured by the Gallup poll) ${ }^{120}$-with between 46 and 58 percent of their populations categorized as "very religious" - support for same-sex marriage is extremely low (ranging from 23 to 35 percent ). ${ }^{121}$ All twelve of the most religious states have constitutional bans on same-sex marriage. In Mississippi, the most religious state in the United States, the state's same-sex marriage ban passed with 86 percent of the vote. ${ }^{122}$ Of the states where same-sex marriage bans passed with more than 75 percent of the vote-Mississippi (86 percent), Tennessee (81 percent), Alabama (81 percent), Louisiana (78 percent), South Carolina (78 percent), Texas (76 percent), Oklahoma (76 percent), Georgia (76 percent), and Arkansas ( 75 percent) - all are extremely religious (58 percent, 50 percent, 56 percent, 53 percent, 52 percent, 47 percent, 48 percent, 48 percent, and 52 percent of the population categorized as "very religious," respectively). ${ }^{123}$ The South, in which same-sex marriage bans exist in every state, comprises the most religious region of the country. ${ }^{124}$

120. These states and their populations, categorized by religiosity, are as follows: Mississippi (58 percent classified as "very religious"), Utah (56 percent), Alabama (56 percent ), Louisiana (53 percent), Arkansas (52 percent), South Carolina (52 percent), Tennessee (50 percent), North Carolina (50 percent), Georgia (48 percent), Oklahoma (48 percent), Texas (47 percent ), and South Dakota (46 percent).

121. Frank Newport, supra note 8; Jeffrey R. Lax \& Justin H. Phillips, Gay Rights in the States: Public Opinion and Policy Responsiveness, 103 AM. POL. SCI. ReV., 373, n.2 (Aug. 2009), available at $\mathrm{http} / / / \mathrm{www} . c o l u m b i a . e d u / \sim j r 12124 /$ Lax_Phillips_Gay_Policy_Responsiveness_2009. pdf. Low support for same-sex marriage in these states is as follows: Mississippi (23 percent support same-sex marriage), Utah (25 percent), Alabama (23 percent), Louisiana (30 percent), Arkansas (25 percent), South Carolina (28 percent), Tennessee (26 percent), North Carolina (31 percent), Georgia (30 percent), Oklahoma (25 percent), Texas (32 percent), and South Dakota (35 percent).

122. Deron Dalton, Nine States Least Likely to Legalize Gay Marriage Anytime Soon, HUFFINGTON POST, Jan. 2, 2013, http://archive.is/wSpIh.

123. Newport, supra note 8; Dalton, supra note 122.

124. Newport, supra note 8 ("Southern states and Utah are the most religious areas in the 
In contrast, the least religious region in the country is New England. ${ }^{125}$ Every state in New England has legalized same-sex marriage. Of the twelve states that have the highest support in polling data for same-sex marriageVermont, Massachusetts, Rhode Island, Connecticut, New York, New Hampshire, California, Hawaii, Maine, Washington, New Jersey, and Colorado-their religiosity is low (ranging from 19 percent to 35 percent of their populations categorized as "very religious"). ${ }^{126}$

According to an analysis performed by Frank Newport, the Editor-in-Chief of Gallup, these geographic differences in religiosity cannot be explained by demographic factors, such as age, education, or race, but rather reflect what Newport describes as "differences in regional cultural traditions."127

Thus, there is a very clear link between religiosity and support for same-sex marriage. The correlation should be clear from Figures 1 and 2, which plot support for same-sex marriage against religiosity for the fifty states, using two different Gallup polls for religiosity. "”,

\section{FIGURE 128}

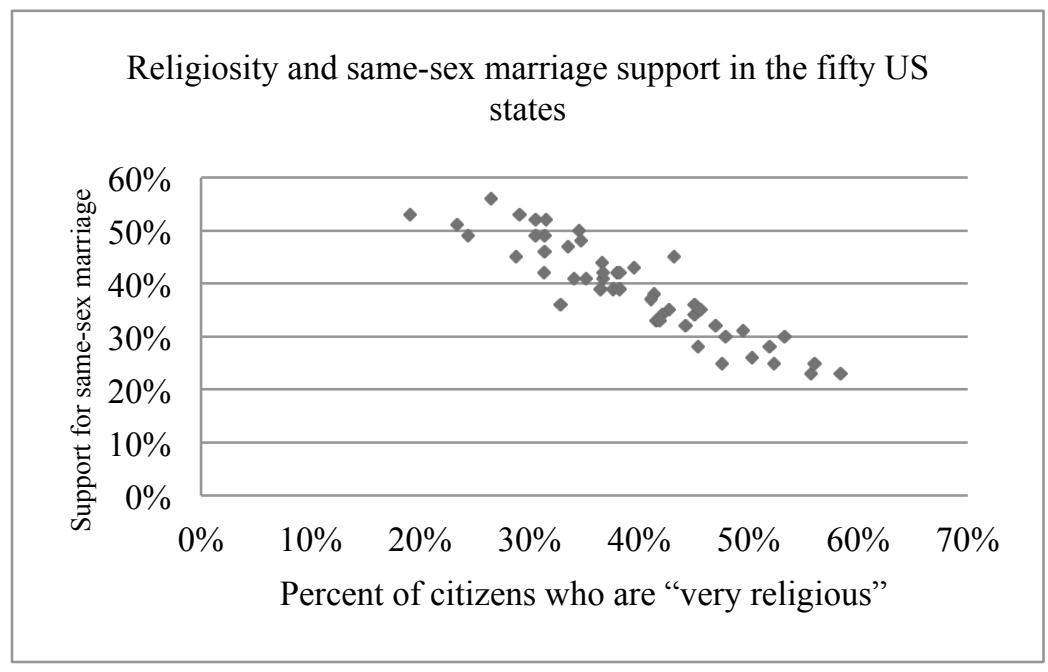

nation.").

125. Id. ("The 12 least religious states comprise the entirety of New England. ..").

126. Newport, surpra note 8; Lax, supra note 121.

127. Newport, supra note 8 (citing Newport's book, God is Alive and Well) (except, according to Newport, for Utah, where demographics (a large Mormon population) does explain the state's religiosity).

128. Newport, supra note 8; Lax, supra note 121. 


\section{FIGURE $2^{129}$}

Religiosity and same-sex marriage support in the fifty US states

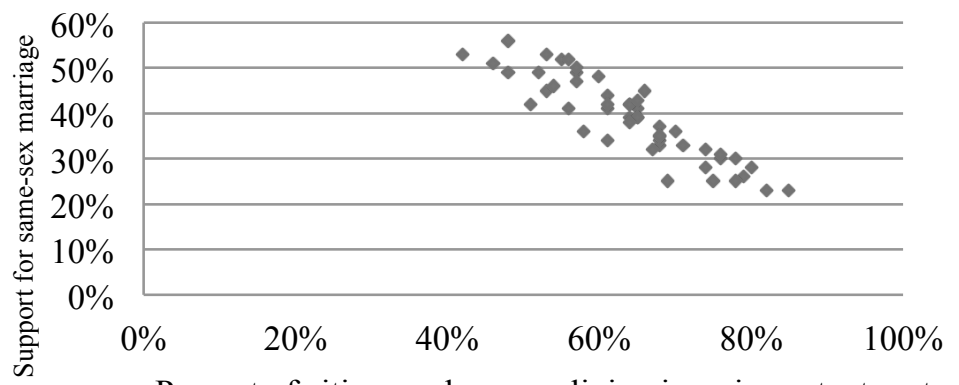

Percent of citizens who say religion is an important part of their daily life

Same-sex marriage support is higher in states that have a higher share of religiously unaffiliated citizens (see Figure 3).

\section{FigURE $3^{130}$}

Religiosity and same-sex marriage support in the continental US

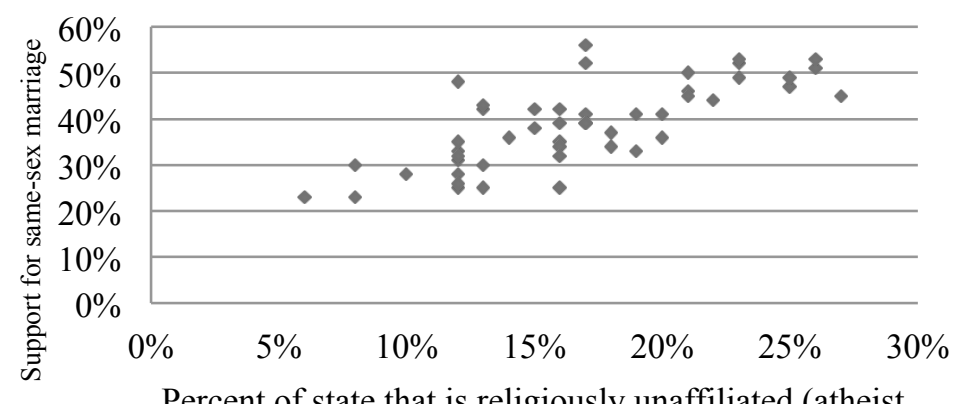

Percent of state that is religiously unaffiliated (atheist, agnostic, or no religion)

129. Frank Newport, State of the States: Importance of Religion, GaLLUP (Jan. 28, 2009), http://www.gallup.com/poll/114022/state-states-importance-religion.aspx\#2; Lax, supra note 121.

130. Lax, supra note 121; U.S. Religious Landscape Survey, Pew RESEARCH CTR., 100 (Feb. 2008), http://religions.pewforum.org/pdf/report-religious-landscape-study-full.pdf. 
In general, same-sex couples choose to live in the least religious states and avoid living in the most religious states (see Figure 4). ${ }^{131}$

FIGURE $4^{132}$

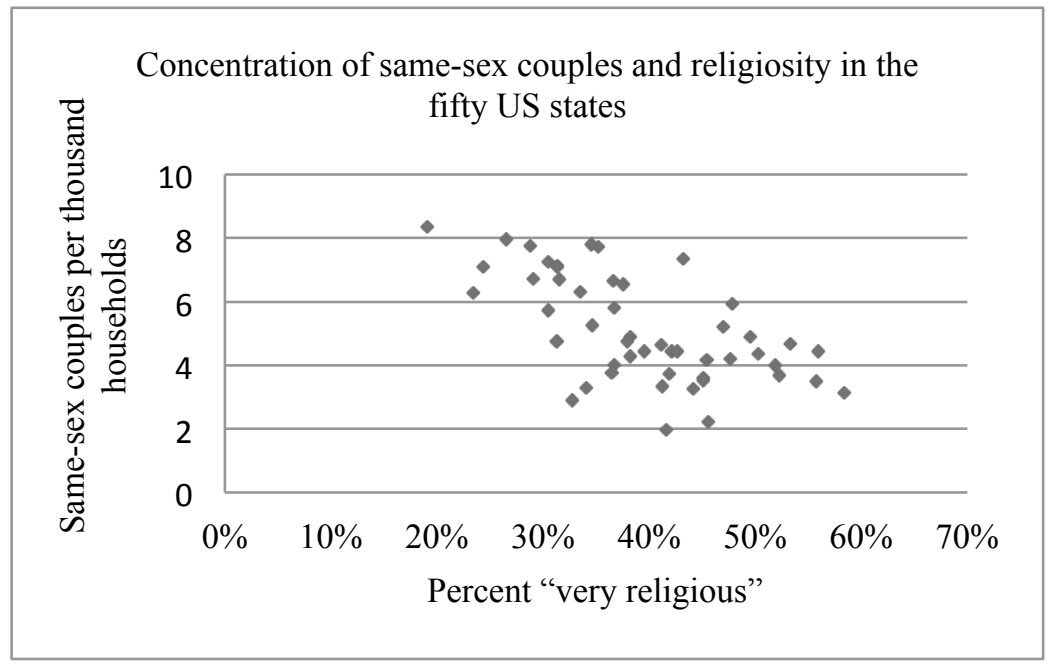

This trend is not surprising given that the more religious states are less supportive of same-sex relationships.

In addition, Washington D.C. has the largest concentration of same-sex couples in the entire nation (with eighteen same-sex couples per thousand households, more than twice the concentration of the highest state-Vermont, which has eight same-sex couples per thousand households). ${ }^{133}$ It is difficult to determine whether the District of Columbia's large concentration of same-sex couples is based on its low religiosity (only 30 percent of the population is "very religious"), ${ }^{134}$ its early adoption of domestic partnerships in 1992, the desirability of living in the nation's capital, or mere random variance resulting from focusing on such a small geographic unit. Regardless, the District of Columbia remains a very favorable environment for same-sex couples, given its adoption of same-sex marriage.

131. However, this trend does not hold for Black same-sex couples, who tend to live in the South, where there are the largest overall concentrations of Blacks generally. See Alain Dang \& Somjen Frazer, Black Same-Sex Households in the United States, NAT'L GAY AND LESBIAN TASK FORCE POLICY INST., 22 (Dec. 2005), http://www.thetaskforce.org/downloads/reports/reports/2000 BlackSameSexHouseholds.pdf. Thus, for Black same-sex couples, race seems to swamp the effect of religiosity in determining where to locate.

132. Gary J. Gates, Abigail M. Cook, United States Census Snapshot 2010, THE WiLliams INST., 5 (Sept. 2011), http://williamsinstitute.law.ucla.edu/wp-content/uploads/Census2010SnapshotUS-v2.pdf.

133. Id.

134. Newport, supra note 129. 
Table 1 below displays religiosity, attitudes towards same-sex marriage, and state policies towards same-sex relationships in the fifty US states.

TABLE 1

\begin{tabular}{|c|c|c|c|}
\hline State & $\begin{array}{l}\text { People } \\
\text { categorized } \\
\text { as "very } \\
\text { religious" } 135\end{array}$ & $\begin{array}{l}\text { Support for } \\
\text { same-sex } \\
\text { marriage }\end{array}$ & $\begin{array}{l}\text { Current state } \\
\text { policy towards } \\
\text { same-sex } \\
\text { relationships } 137\end{array}$ \\
\hline Vermont & $19 \%$ & $53 \%$ & $\begin{array}{l}\text { Same-sex } \\
\text { marriage }\end{array}$ \\
\hline $\begin{array}{l}\text { New } \\
\text { Hampshire }\end{array}$ & $23 \%$ & $51 \%$ & $\begin{array}{l}\text { Same-sex } \\
\text { marriage }\end{array}$ \\
\hline Maine & $24 \%$ & $49 \%$ & $\begin{array}{l}\text { Same-sex } \\
\text { marriage }\end{array}$ \\
\hline Massachusetts & $26 \%$ & $56 \%$ & $\begin{array}{l}\text { Same-sex } \\
\text { marriage }\end{array}$ \\
\hline Oregon & $29 \%$ & $45 \%$ & $\begin{array}{l}\text { Domestic } \\
\text { partnerships, } \\
\text { Constitutional } \\
\text { marriage ban } \\
\end{array}$ \\
\hline Rhode Island & $29 \%$ & $53 \%$ & $\begin{array}{l}\text { Same-sex } \\
\text { marriage }\end{array}$ \\
\hline Connecticut & $30 \%$ & $52 \%$ & $\begin{array}{l}\text { Same-sex } \\
\text { marriage }\end{array}$ \\
\hline Washington & $30 \%$ & $49 \%$ & $\begin{array}{l}\text { Same-sex } \\
\text { marriage }\end{array}$ \\
\hline Alaska & $31 \%$ & $42 \%$ & $\begin{array}{l}\text { Constitutional } \\
\text { marriage ban }\end{array}$ \\
\hline Hawaii & $31 \%$ & $49 \%$ & $\begin{array}{l}\text { Civil unions, } \\
\text { Statutory } \\
\text { marriage ban }\end{array}$ \\
\hline Nevada & $31 \%$ & $46 \%$ & $\begin{array}{l}\text { Domestic } \\
\text { partnerships, } \\
\text { Constitutional } \\
\text { marriage ban } \\
\end{array}$ \\
\hline New York & $31 \%$ & $52 \%$ & $\begin{array}{l}\text { Same-sex } \\
\text { marriage }\end{array}$ \\
\hline Wyoming & $33 \%$ & $36 \%$ & $\begin{array}{l}\text { Statutory } \\
\text { marriage ban }\end{array}$ \\
\hline
\end{tabular}

135. Newport, supra note 129.

136. Lax, supra note 121.

137. NCSL, State Laws Limiting Marriage to Opposite-Sex Couples, supra note 3; NCSL, Civil Unions \& Domestic Partnership Statutes, supra note 2. 


\begin{tabular}{|l|l|l|l|}
\hline Colorado & $33 \%$ & $47 \%$ & $\begin{array}{l}\text { Civil unions, } \\
\text { Constitutional } \\
\text { marriage ban }\end{array}$ \\
\hline Montana & $34 \%$ & $41 \%$ & $\begin{array}{l}\text { Constitutional } \\
\text { marriage ban }\end{array}$ \\
\hline California & $34 \%$ & $50 \%$ & $\begin{array}{l}\text { Same-sex } \\
\text { marriage }\end{array}$ \\
\hline New Jersey & $35 \%$ & $48 \%$ & Civil unions ${ }^{138}$ \\
\hline Delaware & $35 \%$ & $41 \%$ & $\begin{array}{l}\text { Same-sex } \\
\text { marriage }\end{array}$ \\
\hline Michigan & $36 \%$ & $39 \%$ & $\begin{array}{l}\text { Constitutional } \\
\text { marriage ban }\end{array}$ \\
\hline Arizona & $37 \%$ & $44 \%$ & $\begin{array}{l}\text { Constitutional } \\
\text { marriage ban }\end{array}$ \\
\hline Wisconsin & $37 \%$ & $42 \%$ & $\begin{array}{l}\text { Domestic } \\
\text { partnerships, } \\
\text { Constitutional } \\
\text { marriage ban }\end{array}$ \\
\hline Maryland & $37 \%$ & $41 \%$ & $\begin{array}{l}\text { Same-sex } \\
\text { marriage }\end{array}$ \\
\hline Florida & $38 \%$ & $39 \%$ & $\begin{array}{l}\text { Constitutional } \\
\text { marriage ban }\end{array}$ \\
\hline Illinois & $38 \%$ & $42 \%$ & $\begin{array}{l}\text { Civil unions, } \\
\text { Statutory } \\
\text { marriage ban }\end{array}$ \\
\hline Minnesota & $38 \%$ & $42 \%$ & $\begin{array}{l}\text { Same-sex } \\
\text { marriage }\end{array}$ \\
\hline Ohio & $38 \%$ & $39 \%$ & $\begin{array}{l}\text { Constitutional } \\
\text { marriage ban }\end{array}$ \\
\hline Pennsylvania & $40 \%$ & $43 \%$ & $\begin{array}{l}\text { Statutory } \\
\text { marriage ban }\end{array}$ \\
\hline Virginia & $41 \%$ & $37 \%$ & $\begin{array}{l}\text { Constitutional } \\
\text { marriage ban }\end{array}$ \\
\hline Iowa & $41 \%$ & $38 \%$ & $\begin{array}{l}\text { Same-sex } \\
\text { marriage }\end{array}$ \\
\hline North Dakota & $42 \%$ & $33 \%$ & $\begin{array}{l}\text { Constitutional } \\
\text { marriage ban }\end{array}$ \\
\hline West Virginia & $42 \%$ & $33 \%$ & $\begin{array}{l}\text { Statutory } \\
\text { marriage ban }\end{array}$ \\
\hline Missouri & $42 \%$ & $34 \%$ & $\begin{array}{l}\text { Constitutional } \\
\text { marriage ban }\end{array}$ \\
\hline Indiana & $43 \%$ & $\begin{array}{l}\text { Statutory } \\
\text { marriage ban }\end{array}$ \\
\hline
\end{tabular}

138. As this Article went to press, New Jersey legalized same-sex marriage. 


\begin{tabular}{|l|l|l|l|}
\hline New Mexico & $43 \%$ & $45 \%$ & No recognition \\
\hline Nebraska & $44 \%$ & $32 \%$ & $\begin{array}{l}\text { Constitutional } \\
\text { marriage ban }\end{array}$ \\
\hline Kansas & $45 \%$ & $36 \%$ & $\begin{array}{l}\text { Constitutional } \\
\text { marriage ban }\end{array}$ \\
\hline Idaho & $45 \%$ & $34 \%$ & $\begin{array}{l}\text { Constitutional } \\
\text { marriage ban }\end{array}$ \\
\hline Kentucky & $45 \%$ & $28 \%$ & $\begin{array}{l}\text { Constitutional } \\
\text { marriage ban }\end{array}$ \\
\hline South Dakota & $46 \%$ & $35 \%$ & $\begin{array}{l}\text { Constitutional } \\
\text { marriage ban }\end{array}$ \\
\hline Texas & $47 \%$ & $32 \%$ & $\begin{array}{l}\text { Constitutional } \\
\text { marriage ban }\end{array}$ \\
\hline Oklahoma & $48 \%$ & $25 \%$ & $\begin{array}{l}\text { Constitutional } \\
\text { marriage ban }\end{array}$ \\
\hline Georgia & $48 \%$ & $30 \%$ & $\begin{array}{l}\text { Constitutional } \\
\text { marriage ban }\end{array}$ \\
\hline North Carolina & $50 \%$ & $31 \%$ & $\begin{array}{l}\text { Constitutional } \\
\text { marriage ban }\end{array}$ \\
\hline Tennessee & $50 \%$ & $26 \%$ & $\begin{array}{l}\text { Constitutional } \\
\text { marriage ban }\end{array}$ \\
\hline South Carolina & $52 \%$ & $28 \%$ & $\begin{array}{l}\text { Constitutional } \\
\text { marriage ban }\end{array}$ \\
\hline Arkansas & $52 \%$ & $25 \%$ & $\begin{array}{l}\text { Constitutional } \\
\text { marriage ban }\end{array}$ \\
\hline Louisiana & $53 \%$ & $30 \%$ & $\begin{array}{l}\text { Constitutional } \\
\text { marriage ban }\end{array}$ \\
\hline Alabama & $56 \%$ & $23 \%$ & $\begin{array}{l}\text { Constitutional } \\
\text { marriage ban }\end{array}$ \\
\hline Utah & $56 \%$ & $25 \%$ & $\begin{array}{l}\text { Constitutional } \\
\text { marriage ban }\end{array}$ \\
\hline Mississippi & $58 \%$ & $23 \%$ & $\begin{array}{l}\text { Constitutional } \\
\text { marriage ban }\end{array}$ \\
\hline
\end{tabular}

Religiosity thus has a demonstrated correlation with same-sex marriage support. In addition, there are many other factors that appear to affect same-sex marriage support because they co-correlate with religiosity, such as age, religious sect, race, party affiliation, and political ideology.

\section{Age \& Religiosity}

There are also significant generational differences in support for same-sex marriage. In general, support for same-sex marriage is stronger among younger Americans, who as a group are less religious than older generations. Millennials are four times more likely than their grandparents' generation and two times more likely than their parents' generation to be "religiously unaffiliated" (self- 
describing their religion as "atheist," "agnostic," or "nothing in particular"). ${ }^{139}$ Twenty-six percent of millennials, 20 percent of generation X, 13 percent of baby boomers, and 8 percent of the silent generation self-describe as either atheist, agnostic, or unaffiliated with any particular religion. ${ }^{140}$ Church attendance is also down among younger generations. Eighteen percent of millennials, 27 percent of generation X, 32 percent of baby boomers, and 44 percent of the silent generation attend church regularly. ${ }^{141}$ We suspect that because millennials are less religious, they have less rigid viewpoints on homosexuality. Seventy percent of the silent generation, 56 percent of baby boomers, 47 percent of generation X, and 43 percent of millennials say same-sex relationships are "always wrong." 142 Correspondingly, millennials are 2.25 times more likely than their grandparents and 1.84 times more likely than their parents to support same-sex marriage. ${ }^{143}$ Thus, religiosity may explain a large part of the reason why millennials are much more supportive of same-sex marriage than older generations.

\section{Religious Affiliation}

Religious affiliation clearly correlates to support for same-sex marriage. In 2013, 74 percent of the religiously unaffiliated, 55 percent of white mainline Protestants, 54 percent of Catholics, and 23 percent of white evangelical Protestants supported same-sex marriage. ${ }^{144}$ In general, evangelical Protestants are much less supportive of homosexual rights than are mainline Protestants or Catholics. ${ }^{145}$ These denominational differences can explain much of the regional variation in same-sex marriage support in the United States. ${ }^{146}$ The South, which is most opposed to same-sex marriage, has the heaviest concentration of evangelicals "by a wide margin." ${ }^{147}$ The Northeast has the largest concentration of Catholics, and it tends to be more supportive of same-sex marriage, perhaps because Catholics are one of the more supportive religious denominations (along

139. Religion Among the Millennials, PEW RESEARCH CTR. (Feb. 17, 2010), http://archive.is/ OaK5m.

140. Id.

141. Id.

142. Id.

143. PEW RESEARCH CTR., supra note 28. In March 2013, 70 percent of millennials, 38 percent of baby boomers, and 31 percent of the silent generation supported same-sex marriage.

144. Changing Attitudes on Gay Marriage, PEW RESEARCH CTR. (Mar. 2013), http://archive.is/HohJV.

145. Darren E. Sherkat, Kylan Mattias de Vries \& Stacia Creek, Race, Religion, and Opposition to Same-Sex Marriage, 91 SOC. SCI. Q. 80, 82 (2010).

146. Sixty-two percent of New England, 57 percent of mid-Atlantic, 54 percent of Pacific Coast, 42 percent of South Atlantic, and 35 percent of South Central support same-sex marriage. Behind Gay Marriage Momentum, Regional Gaps Persist, Pew ResearCh CtR. (Nov. 9, 2012), http://www.people-press.org/2012/11/09/behind-gay-marriage-momentum-regional-gaps-persist/.

147. Report 1: Religious Affiliation, Summary of Key Findings, PEW RESEARCH CTR. (2007), http://religions.pewforum.org/reports. 
with mainline Protestants). ${ }^{148}$ Lastly, the West, which tends to be quite supportive of same-sex marriage, has the highest concentration of atheists and agnostics. ${ }^{149}$

As the most religious group, evangelical support for same-sex marriage is the lowest among Protestant denominations, perhaps save Mormonism (which may engender even lower support for same-sex marriage). Thus, as depicted below in Figure 5, the fewer evangelicals in a state, the higher the support for same-sex marriage.

\section{FIGURE $5^{150}$}

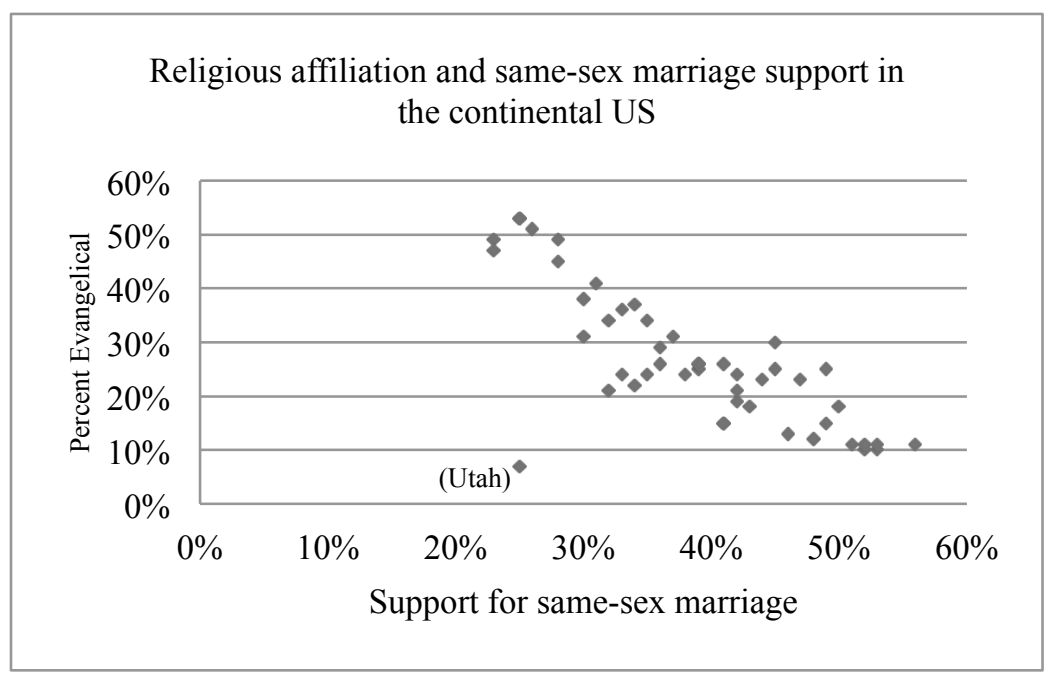

Utah, however, is an outlier because of its large share of Mormons (58 percent of the state population). ${ }^{151}$ Mormons appear to have comparably low levels of support for same-sex marriage.

\section{Race}

In addition, while Blacks are generally less supportive of same-sex marriage than whites (38 percent of Blacks as compared to 50 percent of whites support same-sex marriage), ${ }^{152}$ Darren Sherkat et al. found that these racial differences in same-sex marriage support can be wholly explained by

148. Id

149. Id.

150. PEW RESEARCH CTR., U.S. Religious Landscape Survey, supra note 130; Lax, supra note 121.

151. PeW ReSEARCh CTR., U.S. Religious Landscape Survey, supra note 130.

152. Changing Attitudes on Gay Marriage, PEW RESEARCH CTR. (June 2013), http://archive.is/9QR60. 
differences in denominational ties and religious participation. ${ }^{153}$ The support gap cannot be explained by differences in political values, educational attainment, income, or gender. ${ }^{154}$

These racial differences initially appeared to have been erased by President Obama's announcement of his support for same-sex marriage. There was an immediate 18 percentage point jump in Black support for same-sex marriage following the President's announcement. ${ }^{155}$ While at first this jump in support seemed to have eliminated the Black-white gap in support for same-sex marriage, ${ }^{156}$ recent Pew data shows that the gap still persists, and this jump in support was likely only temporary. ${ }^{157}$

In the recent Proposition 8 vote in California, much blame was leveled at the Black community because exit polls showed that 70 percent of Black voters voted in favor of Proposition 8. ${ }^{158}$ However, Professor Russell Robinson pointed out that not only were exit polls wrong and only 58 percent of Blacks voted for Proposition 8, but also the differences in voting behavior between whites and Blacks could be wholly explained by differences in religiosity, not race. ${ }^{159}$ Professor Robinson, citing a study by Patrick Egan et al., stated that "once the authors controlled for religion, there were no significant racial differences. Thus, the biggest difference between the white vote and the Black vote is not race, but religion." 160 Not only did the Egan study find that religiosity fully explained the Black-white differential in Proposition 8 voting, ${ }^{161}$ but it also found that among all voters, those that attended religious services "weekly or more often" were 22 percentage points more likely to support Proposition 8 than voters who attended only monthly. ${ }^{162}$ Thus, the degree of religiosity not only affected Black voting patterns, but also had a large overall effect on Proposition 8 voting behavior.

To sum up, there has been a rapid shift in public opinion since 2003, which can partly be explained by decreased stigma and partly by a greater proportion

153. Sherkat, at 93-94, supra note 145 .

154. Id.

155. Gene Demby, Poll: Majority Of Blacks Support Gay Marriage After Obama's Endorsement, THE HuFFINGTON POST (May 23, 2012), http://archive.is/XrEjd.

156. Marjorie Connelly, Support for Gay Marriage Growing, but U.S. Remains Divided, N. Y. TIMES (Dec. 7, 2012), http://www.nytimes.com/2012/12/08/us/justices-consider-same-sex-marriagecases-for-docket.html.

157. Changing Attitudes on Gay Marriage, Pew RESEARCH CTR. (Mar. 2013), http://features.pewforum.org/same-sex-marriage-attitudes/slide6.php.

158. Russell K. Robinson, Marriage Equality \& Post-Racialism, 9 (Oct. 19, 2012), http://williamsinstitute.law.ucla.edu/wp-content/uploads/Robinson-DRAFT-MEPR10-8-12.pdf.

159. Id. at 17 .

160. Id.

161. Patrick J. Egan \& Kenneth Sherrill, California's Proposition 8: What Happened, and What Does the Future Hold? NAT'L GAY \& LESBIAN TASK FORCE, 11 (Jan. 2009), http://www.thetaskforce.org/downloads/issues/egan_sherrill_prop8_1_6_09.pdf.

162. Id. at 7 . 
of the US population that personally knows someone who is gay, but this shift can also be partially explained by changes in religious attitudes.

\section{Party Affiliation}

Party affiliation has a strong correlation with same-sex marriage support. In 2013, 59 percent of Democrats and 57 percent of Independents, but only 29 percent of Republicans support same-sex marriage. ${ }^{163}$ Support has also grown more among Democrats and Independents. Since 2004, Republican support for same-sex marriage has grown by twelve percentage points (from 17 to 29 percent), whereas support among Democrats has grown 19 percentage points (from 40 to 59 percent) and support among Independents has grown 20 percentage points (from 37 to 57 percent). ${ }^{164}$

163. Changing Attitudes on Gay Marriage, PEW ReseARCH CTR. (June 2013), $\mathrm{http}: / /$ archive.is/Sk3Ah.

164. Id. 


\section{Political Ideology}

Self-identified ideology also has a strong correlation with same-sex marriage support. In 2013, 73 percent of liberals and 30 percent of conservatives supported same-sex marriage. ${ }^{165}$ The correlation between ideology and same-sex marriage support is demonstrated in Figure 6. "Conservative advantage," as measured by Gallup, is the percent of self-identified conservatives in the state minus the percent of liberals.

\section{FIGURE $6^{166}$}

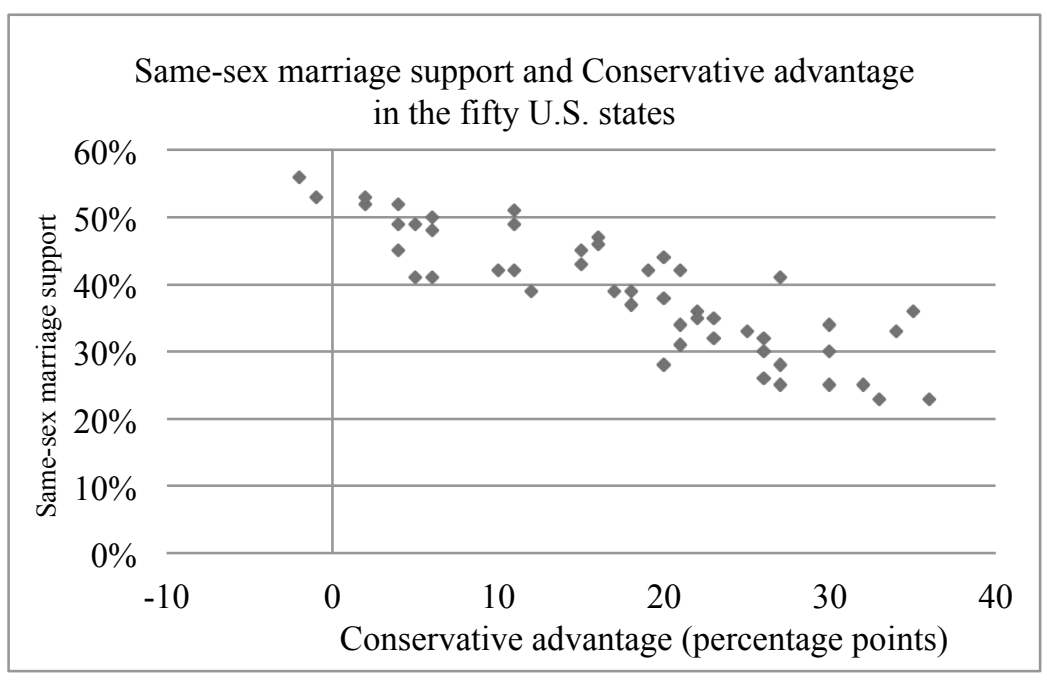

165. Changing Attitudes on Gay Marriage, PEW RESEARCH CTR. (June 2013) http://archive.is/pg04u.

166. Frank Newport, Alabama, North Dakota, Wyoming Most Conservative States, GaLluP (Feb. 1, 2013), http://www.gallup.com/poll/160196/alabama-north-dakota-wyoming-conservativestates.aspx\#2; Lax, supra note 121. 
While political ideology seems to be a relatively strong predictor of samesex marriage support, the correlation for party identification and same-sex marriage support is not quite as strong, as illustrated in Figure 7.

\section{FIGURE $7^{167}$}

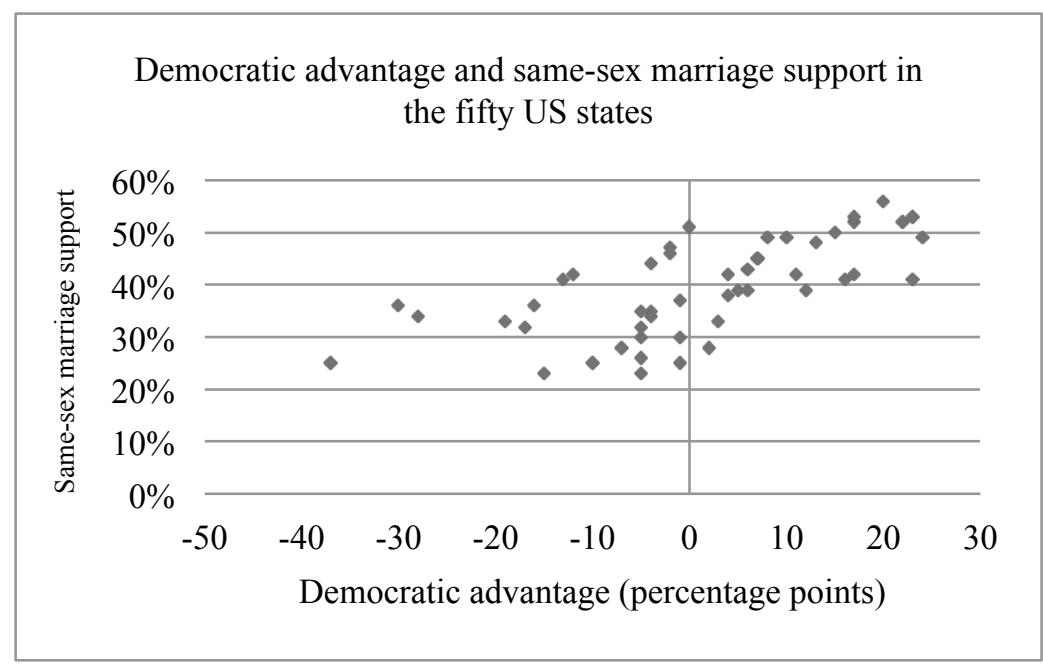

Because of the South's long history-now rapidly disappearing-of support for the Democratic Party, religiosity appears to be a better proxy for conservatism than does party affiliation. For example, Mississippi, the most religious state, whose marriage ban passed with the highest proportion of the vote of any state, is only the 12th most Republican state, but is the 4th most conservative. ${ }^{168}$ Thus, religiosity has an important role to play in predicting public support for same-sex marriage in the United States.

However, the above polls only capture self-reported religiosity, ideology, party affiliation, and same-sex marriage support among a state's citizens. Since not all citizens vote, a state's red or blue status, based on past voting behavior, may be a better predictor of actual state policies towards same-sex marriage. Of the dark red states (states where the Republican won the last four presidential elections), all twenty-two have bans on same-sex marriage, twenty by state constitution and two by statute. ${ }^{169}$ Of the light red states (Republican won three of last four presidential elections), both ban same-sex marriage, one by state

167. Lydia Saad, In the U.S., Blue States Outnumber Red States, 20 to 12, GalluP (Jan. 30, 2013), http://www.gallup.com/poll/160175/blue-states-outnumber-red-states.aspx\#2 (Democratic Advantage, as measured by Gallup, is the percent of Democrats in the state minus the percent of Republicans in the state); Lax, supra note 121.

168. Newport, supra note 166; Saad, supra note 167.

169. Alaska, Arizona, Utah, Idaho, Montana, North Dakota, South Dakota, Nebraska, Kansas, Oklahoma, Texas, Missouri, Arkansas, Louisiana, Mississippi, Alabama, Georgia, South Carolina, Tennessee, Kentucky (Constitutional bans), Wyoming, and West Virginia (statutory bans). 
constitution (North Carolina) and one by statute (Indiana). For purple states (split two-two on presidential elections), all five ban same-sex marriage by state constitution, but two states provide rights to same-sex couples through domestic partnerships or civil unions (Nevada, Colorado). ${ }^{170}$ Of the three light blue states (Democrat won three of last four presidential elections), two allow same-sex marriage (New Hampshire and Iowa), and the other provides no recognition of same-sex relations but has no ban (New Mexico). Of the eighteen dark blue states, two states ban same-sex marriage and provide no other recognition to same-sex couples (Michigan - Constitutional ban, and Pennsylvania - statutory ban), two states ban same-sex marriage but provide civil unions or domestic partnerships (Oregon, Hawaii), three simply provide civil unions or domestic partnerships (Wisconsin, Illinois, New Jersey), and eleven allow same-sex marriage (Washington, Maryland, New York, Connecticut, Massachusetts, Vermont, Maine, Delaware, Rhode Island, Minnesota, California). ${ }^{171}$ Thus, in general, dark red states are more likely to ban same-sex marriage by constitution than by statute (which typically takes more legislative votes or a popular vote), all red states have bans on same-sex marriage and no additional recognition of the rights of same-sex couples (through either civil unions or domestic partnerships), purple states all have bans, but approximately half otherwise provide recognition of same-sex relationships, and blue states comprise the only states to allow same-sex marriage. Those blue states that ban same-sex marriage are more likely to do so by statute (which is more easily reversible), than by state constitution, and even if they ban same-sex marriage, they are still likely to provide recognition of same-sex relationships in the form of civil unions or domestic partnerships.

Thus, to the extent that low religiosity does not match state policies towards same-sex couples, it may be due to lower voter turnout among more liberal citizens. One study, for example, found that in 74 percent of elections, non-voters were disproportionately Democratic. ${ }^{172}$ The religiosity of the population captured in polls may thus not translate into actual votes. Therefore, while religiosity may be a good predictor of general support for same-sex marriage, it may not be quite as good at predicting elections outcomes (such as for ballot initiatives).

170. The other three are Ohio, Virginia, and Florida.

171. See Saad, supra note 167; NCSL, Same Sex Marriage Laws, supra note 1; NCSL, Civil Unions \& Domestic Partnership Statutes, supra note 2; NCSL, State Laws Limiting Marriage to Opposite-Sex Couples, supra note 3.

172. Jack Citrin, Eric Schickler, \& John Sides, What if Everyone Voted? Simulating the Impact of Increased Turnout in Senate Elections, 47 AM. J. OF POL. SCI. 75, 81 (2003), available at http://home.gwu.edu/ jsides/turnout.pdf. 


\section{B. Europe}

The correlation between religiosity and support for same-sex marriage in Europe is not quite as remarkable as that in the United States, but a correlation does exist.

In the European Union, there is a general trend between increased religiosity (as measured by the 2010 Eurobarometer) and decreased support for same-sex marriage, as illustrated in Figure 8.

FIGURE $8^{173}$

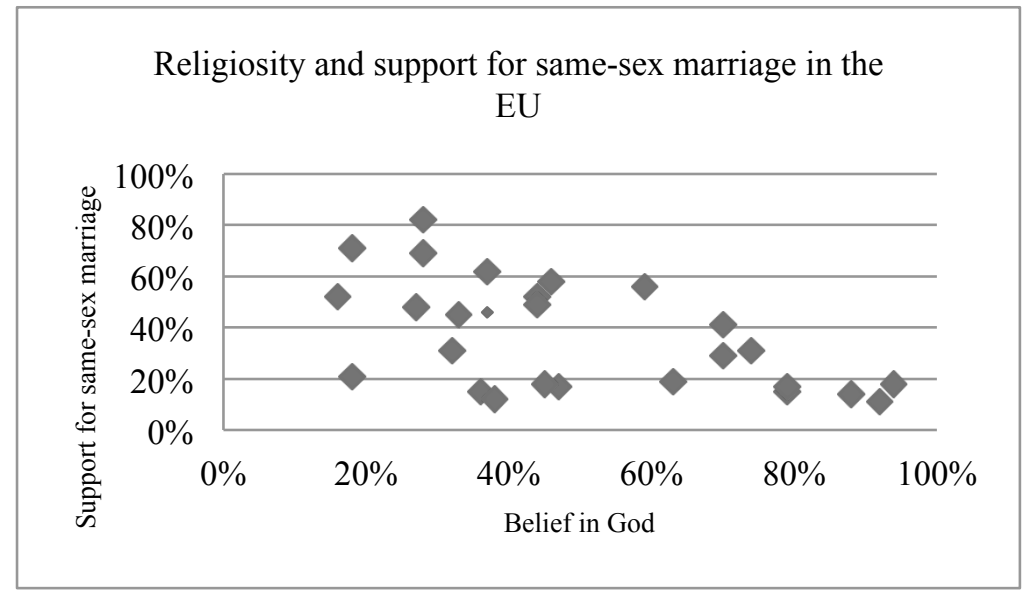

173. Biotechnology, Special Eurobarometer 341/Wave 73.1, EUROBAROMETER, 204 (Oct. 2010), available at http://ec.europa.eu/public_opinion/archives/ebs/ebs_341_en.pdf; EUROBAROMETER, 2.4 Attitudes Towards Homosexuality (2006), supra note 76. 
However, the trend is stronger for the most religious countries than the least religious. In Figure 8, the scatter diagram becomes more tightly arranged as religiosity increases. Thus, the correlation is not as strong for less religious countries. Likewise, in Figure 9, there are a number of countries that do not appear to fit the trend line. Moreover, the contrast is striking when this figure is compared with Figures 1 and 2, depicting the trend in the United States.

\section{FIGURE $9^{174}$}

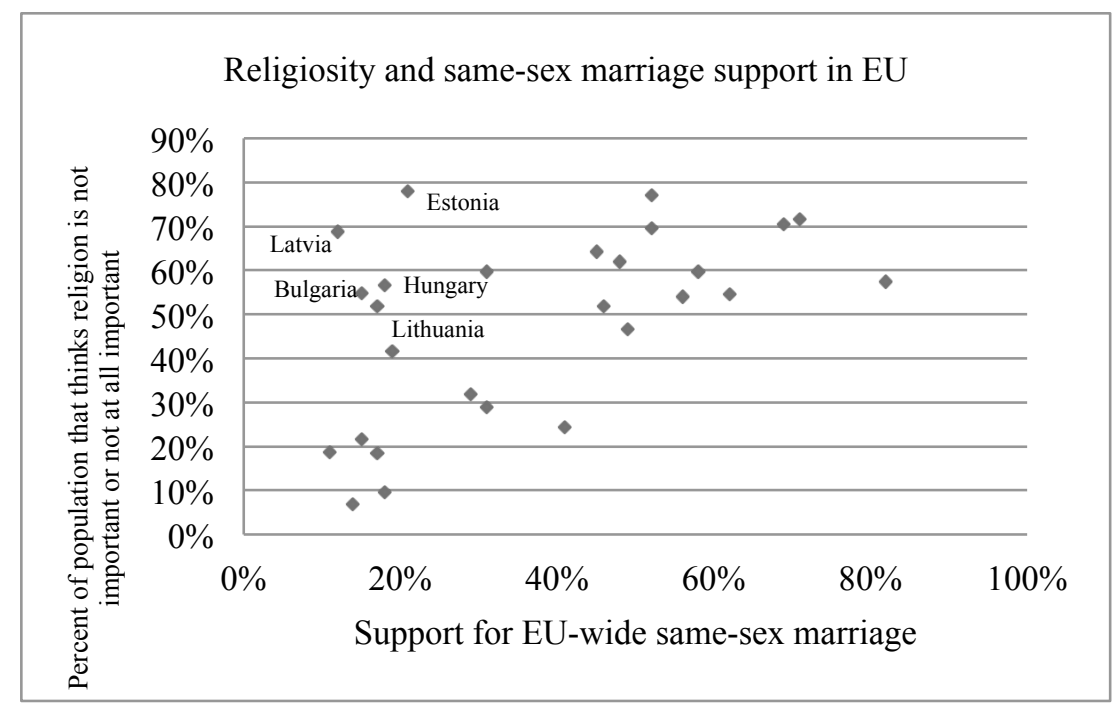

There are five clear outliers in the EU that don't fit the trend line-Estonia, Latvia, Hungary, Bulgaria, Lithuania (countries that are not very religious but have low support for same-sex marriage). Given that most of Eastern Europe remains adamantly opposed to gay rights, we suspect that some other factor, associated with their shared history under communism, correlates with low support for same-sex marriage. There may be some co-correlate with both conservatism and religiosity that we have yet to identify, or it may be that Eastern Europeans are more likely to be atheists than similarly politically conservative Western Europeans because of the legacy impact of the communist suppression of organized religion.

Estonia and Latvia appear to be the largest outliers because of their unique ethnic composition. During Soviet rule, in order to promote the Sovietization of all aspects of life, the Soviets implemented a mass migration program into the

174. Eurobarometer, 2.4 Attitudes Towards Homosexuality (2006), supra note 76; European Value Survey, European Values Study Longitudinal Data File 1981-2008, GESIS DATA ARCHIVE (2011) (we downloaded the survey data and used a data analysis tool to extract the most recent survey data that was available for each country). 
three Baltic states. ${ }^{175}$ While Lithuania does not retain much of its Russian population (only 5 percent of the current population is ethnic Russian), ${ }^{176}$ Estonia and Latvia have retained large ethnic Russian populations (26 percent and 28 percent of the populations, respectively). ${ }^{177}$ Ethnic Russians tend to be much less supportive of gay rights. In Estonia, for example, 51 percent of ethnic Estonians support registered partnerships, but only 35 percent of ethnic Russians do. ${ }^{178}$ This can be partially explained by religiosity because in Estonia, ethnic Russians tend to be "considerably more religious" than ethnic Estonians. ${ }^{179}$

One might hypothesize that the link between religiosity and same-sex marriage opposition has been de-coupled in former Soviet states because if someone is forced to give up her religion, this is not evidence that the conservatism associated with religion has been eliminated, whereas if someone leaves her religion voluntarily, this is evidence of such. The Soviet Union did often engage in forced atheism campaigns in its satellites, often to the point of nationalizing and confiscating all church properties and outlawing religious practices. ${ }^{180}$ If people retained their conservatism but gave up their religion, this would explain why religiosity does not seem to correlate with same-sex marriage support in many Eastern European countries.

This hypothesis, however, does not explain why Estonia remains one of the least religious nations in the EU, but also one of the most strongly opposed to same-sex relationships. Estonia has never had a strong religious tradition, even before the Soviet occupation. ${ }^{181}$ Many Estonians viewed religion as an undesirable tradition performed by the Swedish and German ruling classes. ${ }^{182}$ However, if the hypothesis is modified it may still be valid: if a person leaves her religion, this is evidence of a transformation away from conservatism, but if a person was never religious or was forced to give up her religion, a lack of

175. Davit Mikeladze, Russian-Speaking Population in the Baltic States: A "Fifth Column" or An Integral Part of the Local Society? 13-14 (1994) (Central European University), http://www.units.muohio.edu/havighurstcenter/publications/documents/DavitMikeladze.pdf.

176. CIA World Factbook, Lithuania (2009) (updated Mar. 15, 2013), https://www.cia.gov/ library/publications/the-world-factbook/geos/lh.html.

177. Estonian 68.7 percent, Russian 25.6 percent. CIA World Factbook, Estonia (2008) (updated Mar. 15, 2013), https://www.cia.gov/library/publications/the-world-factbook/geos/en.html; CIA World Factbook, Latvia (2009) (updated Mar. 15, 2013), https://www.cia.gov/library/ publications/the-world-factbook/geos/lg.html.

178. Postimees, Uuring: eestlased pole samasoolistekooseluregistreerimisevastu (Sept. 13, 2012), http://archive.is/58QRs (Est.).

179. Ringo Ringvee, Is Estonia really the least religious country in the world? THE GUARDIAN (Sept. 16, 2011), http://archive.is/Yo0UC.

180. See, e.g., Juris Dreifelds, Religion in Latvia: from Atrophy to Rebirth at 245, http://www.stm.unipi.it/clioh/tabs/libri/8/18-Dreidfels.pdf (discussing the Soviet forced atheism campaign in Latvia).

181. Ringvee, supra note 179.

182. Id. 
religiosity is not evidence of a lack of conservatism, at least as far as gay rights (and potentially other social issues) are concerned.

However, further research is still needed. The above hypothesis does not explain why the Czech Republic, with comparable religiosity to Estonia, displays more than double the support for same-sex marriage and has registered partnerships, while Estonia does not. Both countries consistently rank as the two least religious states in the EU, and both countries appear to be proud of their non-religiosity. ${ }^{183}$ Yet both have such different attitudes towards same-sex marriage (52 percent support in the Czech Republic, compared to 21 percent for Estonia). ${ }^{184}$ These differential levels of same-sex marriage support, but comparable levels of religiosity, would make for an interesting further study.

A regression analysis by Jurgen Gerhards provides one explanation for why religiosity is more explanatory of social attitudes towards homosexuality in Western Europe than Eastern Europe. Gerhards found that in the EU, the more modernized a country becomes, the more supportive its populace becomes of homosexuality (as measured by the question "can homosexuality ever be justified?"). ${ }^{185}$ Education level, as one measure of development, had an independent effect on social attitudes towards homosexuality. ${ }^{186}$ The lower support for same-sex relationships in Eastern Europe may be due to lower levels of economic, social, and political development.

In addition, Gerhards found that religious affiliation affected attitudes towards homosexuality. ${ }^{187}$ Among the denominations, "Orthodox Christians, Catholics and especially Muslims are much more ready to say that homosexuality is not justifiable than are Protestants." 188 In addition, Gerhards found that "religious integration" (as measured by church attendance) also correlated with a person's views on homosexuality. The more frequently a person attended a religious institution, the less likely that person was to view homosexuality as being permissible. ${ }^{189}$ Lastly, Gerhards found that the effect of religious integration on social attitudes towards homosexuality was greater than the effect of religious denomination. ${ }^{190}$ This result means that as far as social attitudes towards homosexuality are concerned, it matters more how fervently someone adheres to her religion than to which religion she belongs.

183. Ringvee, supra note 179.

184. EUROBAROMETER, 2.4 Attitudes Towards Homosexuality (2006), supra note 76.

185. Jurgen Gerhards, Non-Discrimination towards Homosexuality: The European Union's Policy and Citizen's Attitudes towards Homosexuality in 27 European Countries, 25 INT'L Soc. 1, 19 (Jan. 2010), http://www.polsoz.fuberlin.de/soziologie/arbeitsbereiche/makrosoziologie/mitar beiter/lehrstuhlinhaber/dateien/Gerhards-International-Sociology-20101.pdf.

186. Id.

187. Id.

188. Id.

189. Id.

190. Id. 
Table 2 below charts the relationship between non-religiosity and the level of recognition of same-sex relationships in Europe. Table 3 does the same for the European Union, while including attitude surveys towards same-sex marriage from the Eurobarometer.

TABLE 2

Non-religiousness and country policy towards same-sex relationships, for European countries included in the European Value Survey (2008-2010)

\begin{tabular}{|c|c|c|}
\hline Country & $\begin{array}{l}\text { Percent of country } \\
\text { that considers } \\
\text { religion "not } \\
\text { important" or "not } \\
\text { at all important"191 }\end{array}$ & $\begin{array}{l}\text { Country policy } \\
\text { towards same-sex } \\
\text { relationships } 192\end{array}$ \\
\hline Czech Republic & $80 \%$ & $\begin{array}{l}\text { Registered } \\
\text { partnerships }\end{array}$ \\
\hline Sweden & $77 \%$ & Same-sex marriage \\
\hline Estonia & $76 \%$ & No recognition \\
\hline Germany & $73 \%$ & $\begin{array}{l}\text { Registered } \\
\text { partnerships }\end{array}$ \\
\hline Finland & $71 \%$ & $\begin{array}{l}\text { Registered } \\
\text { partnerships }\end{array}$ \\
\hline Denmark & $70 \%$ & Same-sex marriage \\
\hline Latvia & $68 \%$ & $\begin{array}{l}\text { Constitutional } \\
\text { marriage ban }\end{array}$ \\
\hline Norway & $65 \%$ & Same-sex marriage \\
\hline France & $63 \%$ & Same-sex marriage \\
\hline Luxembourg & $62 \%$ & $\begin{array}{l}\text { Registered } \\
\text { partnerships }\end{array}$ \\
\hline Belgium & $61 \%$ & Same-sex marriage \\
\hline Spain & $61 \%$ & Same-sex marriage \\
\hline Hungary & $60 \%$ & $\begin{array}{l}\text { Registered } \\
\text { partnerships }\end{array}$ \\
\hline Slovenia & $59 \%$ & $\begin{array}{l}\text { Registered } \\
\text { partnerships }\end{array}$ \\
\hline Switzerland & $57 \%$ & $\begin{array}{l}\text { Registered } \\
\text { partnerships }\end{array}$ \\
\hline Netherlands & $55 \%$ & Same-sex marriage \\
\hline Lithuania & $54 \%$ & $\begin{array}{l}\text { Constitutional } \\
\text { marriage ban }\end{array}$ \\
\hline
\end{tabular}

191. European Value Survey, GESIS DATA ARCHIVE (2011), supra note 174

192. See MARRIAGE EQUALITY USA, supra note 5. 


\begin{tabular}{|l|l|l|}
\hline Austria & $53 \%$ & $\begin{array}{l}\text { Registered } \\
\text { partnerships }\end{array}$ \\
\hline United Kingdom & $52 \%$ & $\begin{array}{l}\text { Same-sex marriage } \\
\text { (England \& Wales) } \\
\text { Registered } \\
\text { partnerships (Scotland } \\
\text { \& Northern Ireland) }\end{array}$ \\
\hline Iceland & $48 \%$ & Same-sex marriage \\
\hline Russia & $48 \%$ & No recognition \\
\hline Albania & $47 \%$ & No recognition \\
\hline Bulgaria & $45 \%$ & $\begin{array}{l}\text { Constitutional } \\
\text { marriage ban }\end{array}$ \\
\hline Belarus & $45 \%$ & $\begin{array}{l}\text { Constitutional } \\
\text { marriage ban }\end{array}$ \\
\hline Slovakia & $38 \%$ & No recognition \\
\hline Ireland & $33 \%$ & $\begin{array}{l}\text { Registered } \\
\text { partnerships }\end{array}$ \\
\hline Portugal & $33 \%$ & Same-sex marriage \\
\hline Ukraine & $33 \%$ & $\begin{array}{l}\text { Constitutional } \\
\text { marriage ban }\end{array}$ \\
\hline Azerbaijan & $27 \%$ & No recognition \\
\hline Croatia & $27 \%$ & $\begin{array}{l}\text { Unregistered } \\
\text { cohabitation }\end{array}$ \\
\hline Italy & $26 \%$ & No recognition \\
\hline Serbia & $26 \%$ & $\begin{array}{l}\text { Constitutional } \\
\text { marriage ban }\end{array}$ \\
\hline Poland & $3 \%$ & $\begin{array}{l}\text { Constitutional } \\
\text { marriage ban }\end{array}$ \\
\hline Montenegro & $25 \%$ & $\begin{array}{l}\text { Constitutional } \\
\text { marriage ban }\end{array}$ \\
\hline Moldova & $21 \%$ & $\begin{array}{l}\text { Constitutional } \\
\text { marriage ban }\end{array}$ \\
\hline Macedonia & $20 \%$ & No recognition \\
\hline $\begin{array}{l}\text { Bosnia and } \\
\text { Herzegovina }\end{array}$ & $19 \%$ & No recognition \\
\hline Armenia & $15 \%$ & No recognition \\
\hline Greece & $14 \%$ & No recognition \\
\hline Romania & $9 \%$ & No recognition \\
\hline Malta & No recognition \\
\hline Kosovo & No recognition \\
\hline Cyprus & No recognition \\
\hline Georgia & No recognition \\
\hline Turkey & No recognition \\
\hline & $25 \%$ & \\
\hline
\end{tabular}

It is important to note that in comparison to Europe, the United States in the aggregate finds itself among the most religious countries, with only 28 percent 
of Americans saying that religion was not very important or not at all important. ${ }^{193}$ This places the United States with comparable religiosity to Poland and Italy. Only the least religious US state (Vermont-only 19 percent consider themselves "very religious") has remotely comparable religiosity to the least religious states in Europe, such as Belgium (only 12 percent consider religion "very important"), France (13 percent consider religion "very important"), Norway (13 percent consider religion "very important"), and Denmark (9 percent consider religion "very important"). ${ }^{194}$ Moreover, very few nations in Europe are as religious as the most religious US states. Mississippi, the most religious US state (58 percent consider themselves "very religious"), finds very few comparable countries in Europe. Only Georgia (67 percent consider religion "very important"), Greece (46 percent), Malta (65 percent), Romania (57 percent), Kosovo (48 percent), and Turkey ( 80 percent) have comparably high levels of religiosity. ${ }^{195}$ Looking only at Western Europe, the most traditionally religious countries, such as Northern Ireland (36 percent consider religion "very important") or Portugal (24 percent), would - if they were a US state-find themselves among the ten least religious states in the United States. ${ }^{196}$ Thus, compared to Western Europe, the least religious US states tend to be more religious than the most religious Western European countries, and the most religious US states tend to be far more religious than the most religious Western European countries.

In the European Union, religiosity is tied closely to same-sex marriage support, with some notable exceptions. The Baltic states (Estonia, Latvia, Lithuania) appear to be outliers, in that their support should be higher based on their low religiosity. Spain and Portugal, at the other end of the spectrum, are outliers because it is surprising that they have same-sex marriage given their high levels of religiosity (see Table 3 ).

193. United States (General): Public Opinion, Ass'N OF Religious DATA ARChIVES, http://www.thearda.com/internationalData/countries/Country_234_5.asp. (last visited November 2, 2013) (citing data calculated by the ARDA based on material from the 2005 World Values Survey, an investigation of socio-cultural and political change conducted by a network of social scientists at leading universities around the world).

194. European Value Survey, GESIS DATA ARCHIVE (2011), supra note 174.

195. Id.

196. Id. 
TABLE 3

Belief in God, support for same-sex marriage, and national policy in the European Union

\begin{tabular}{|l|l|l|l|}
\hline Country & $\begin{array}{l}\text { Believes there is } \\
\text { a God } \\
\text { Eurobarometer }^{\text {2010) }}{ }^{197}\end{array}$ & $\begin{array}{l}\text { Support for } \\
\text { EU-wide same- } \\
\text { sex marriage } \\
\text { (Eurobarometer } \\
\mathbf{2 0 0 6})^{198}\end{array}$ & $\begin{array}{l}\text { Country policy } \\
\text { towards same- } \\
\text { sex } \\
\text { relationships }\end{array}$ \\
\hline $\begin{array}{l}\text { Czech } \\
\text { Republic }\end{array}$ & $16 \%$ & $52 \%$ & $\begin{array}{l}\text { Registered } \\
\text { partnerships }\end{array}$ \\
\hline Estonia & $18 \%$ & $21 \%$ & No recognition \\
\hline Sweden & $18 \%$ & $71 \%$ & $\begin{array}{l}\text { Same-sex } \\
\text { marriage }\end{array}$ \\
\hline France & $27 \%$ & $48 \%$ & $\begin{array}{l}\text { Same-sex } \\
\text { marriage }\end{array}$ \\
\hline Denmark & $28 \%$ & $69 \%$ & $\begin{array}{l}\text { Same-sex } \\
\text { marriage }\end{array}$ \\
\hline Netherlands & $28 \%$ & $82 \%$ & $\begin{array}{l}\text { Same-sex } \\
\text { marriage }\end{array}$ \\
\hline Slovenia & $32 \%$ & $31 \%$ & $\begin{array}{l}\text { Registered } \\
\text { partnerships }\end{array}$ \\
\hline Finland & $33 \%$ & $45 \%$ & $\begin{array}{l}\text { Registered } \\
\text { partnerships }\end{array}$ \\
\hline Bulgaria & $36 \%$ & $15 \%$ & $\begin{array}{l}\text { Constitutional } \\
\text { marriage ban }\end{array}$ \\
\hline & & $46 \%$ & $\begin{array}{l}\text { Same-sex } \\
\text { marriage } \\
\text { (England \& } \\
\text { Wales) } \\
\text { Registered } \\
\text { partnerships } \\
\text { (Scotland \& } \\
\text { Northern } \\
\text { Ireland) }\end{array}$ \\
\hline $\begin{array}{l}\text { United } \\
\text { Kingdom }\end{array}$ & $37 \%$ & & \\
\hline
\end{tabular}

197. EUROBAROMETER, Biotechnology, Special Eurobarometer 341/Wave 73.1, supra note 173

198. Eurobarometer, 2.4 Attitudes Towards Homosexuality (2006), supra note 76. These statistics were confirmed in 2011 regarding France, Germany, the United Kingdom, Hungary, Italy, the Netherlands, Portugal and Poland (with 52\% in France, $40 \%$ in Germany, $42 \%$ in United Kingdom, $70 \%$ in Hungary, $64 \%$ in Italy, $17 \%$ in the Netherlands, $62 \%$ in Portugal, and $88 \%$ in Poland answering that allowing gay marriage is not a good thing). Andreas Zick, Beate Kupper, \& Andreas Hovermann, Intolerance, Prejudice and Discrimination - A European Report, THE FRIEDRICH-EBERT-STIFTUNG FOUNDATION, 64-65 (2011), available at http://library.fes.de/pdffiles/do/07908-20110311.pdf.

199. MARRIAGE EQUALITY USA, supra note 5. 


\begin{tabular}{|l|l|l|l|}
\hline Belgium & $37 \%$ & $62 \%$ & $\begin{array}{l}\text { Same-sex } \\
\text { marriage }\end{array}$ \\
\hline Latvia & $38 \%$ & $12 \%$ & $\begin{array}{l}\text { Constitutional } \\
\text { marriage ban }\end{array}$ \\
\hline Austria & $44 \%$ & $49 \%$ & $\begin{array}{l}\text { Registered } \\
\text { partnerships }\end{array}$ \\
\hline Germany & $44 \%$ & $52 \%$ & $\begin{array}{l}\text { Registered } \\
\text { partnerships }\end{array}$ \\
\hline Hungary & $45 \%$ & $18 \%$ & $\begin{array}{l}\text { Registered } \\
\text { partnerships }\end{array}$ \\
\hline Luxembourg & $46 \%$ & $58 \%$ & $\begin{array}{l}\text { Registered } \\
\text { partnerships }\end{array}$ \\
\hline Lithuania & $47 \%$ & $17 \%$ & $\begin{array}{l}\text { Constitutional } \\
\text { marriage ban }\end{array}$ \\
\hline Spain & $59 \%$ & $56 \%$ & $\begin{array}{l}\text { Same-sex } \\
\text { marriage }\end{array}$ \\
\hline Slovakia & $63 \%$ & $19 \%$ & No recognition \\
\hline Ireland & $70 \%$ & $41 \%$ & $\begin{array}{l}\text { Registered } \\
\text { partnerships }\end{array}$ \\
\hline Portugal & $70 \%$ & $29 \%$ & $\begin{array}{l}\text { Same-sex } \\
\text { marriage }\end{array}$ \\
\hline Italy & $74 \%$ & $31 \%$ & No recognition \\
\hline Greece & $79 \%$ & $15 \%$ & No recognition \\
\hline Poland & $79 \%$ & $17 \%$ & $\begin{array}{l}\text { Constitutional } \\
\text { marriage ban }\end{array}$ \\
\hline Cyprus & $88 \%$ & $14 \%$ & No recognition \\
\hline Romania & $92 \%$ & No recognition \\
\hline Malta & $94 \%$ & No recognition \\
\hline
\end{tabular}

Slovenia is an interesting case. When it passed its domestic partnership law in 2005, granting only limited property rights to same-sex couples, it had a center-right government in power. ${ }^{200}$ The Social Democrats and Liberals refused to take part in the vote for the law because it granted no social benefits to samesex couples (such as Social Security), provided no health insurance benefits, did not allow same-sex couples to be next-of-kin, and contained an explicit statement that marriage was not permitted. ${ }^{201}$ In 2010, a left-leaning government proposed an amendment to the family code that would have legalized same-sex marriage, but Conservatives later removed this from the bill. ${ }^{202}$ The final bill, which would have merely equalized the rights of domestic partners and

200. Slovenia - Politics, Global SeCURITY (updated Nov. 16, 2012), http://archive.is/r5e9p.

201. See Andy Humm, News Brief, 4 GAY CITY News 25 (June 30-July 6, 2005), http://archive.is/TL763 (the final vote was 44-3 because the Social Democrats and Liberals had left the chamber and refused to participate).

202. SlowenienschrecktvorEhe-Öffnungzurück, QUEER. DE (June 17, 2011), http://archive.is/ W57SX (Ger.). 
heterosexual married couples, ultimately passed, but was later repealed by a popular referendum. ${ }^{203}$ Thus, although a new left-of-center government has come into power in Slovenia, ${ }^{204}$ it is unlikely to be able to make progress towards marriage equality given the high level of opposition to same-sex relationships ( 69 percent of the public oppose same-sex marriage, according to the 2006 Eurobarometer).

One important reason that national policies towards same-sex relationships often do not match religiosity or even same-sex marriage support among the public may be based on the political party currently in power. France, for example, is a very non-religious country ( 27 percent believe in God), but progress towards same-sex marriage has been stalled there until relatively recently. This is because France was led by Jacques Chirac, a Conservative, ${ }^{205}$ (who formed the Union for a Popular Movement (UMP) in 2002), from 1995 until 2007 and was led by Nicolas Sarkozy (the head of the conservative UMP party) from 2007 until 2012. With the recent election of a Socialist majority in the National Assembly and Senate and François Hollande as President, France has placed the Socialist Party back in power and has thus quickly passed a samesex marriage law.

Spain was way ahead of the curve in its legalization of same-sex marriage, in spite of being a very religious country. Spain's legalization of same-sex marriage was due to the election of a Socialist government in 2004. Upon his election, Prime Minister Jose Luis Rodriguez Zapatero (of the Spanish Socialist Workers' Party) pledged to legalize same sex marriage and did so approximately a year later. ${ }^{206}$ The election of socialist governments appears to strongly spur European countries towards same-sex marriage legalization.

It is surprising, likewise, that Portugal legalized same-sex marriage in 2010 , in spite of having a deeply religious population. However, in 2005, Portugal's Socialist party, under the leadership of Prime Minister Jose Socrates, won an absolute majority for the first time in the nation's history. ${ }^{207}$ It was during Socrates's second term that the Parliament passed same-sex marriage legislation, after he announced before the elections his intention to propose it. ${ }^{208}$

203. J.C. von Krempach, supra note 58.

204. Associated Press, Slovenian parliament votes into office new, center-left government to tackle economic downturn; Slovenian parliament approves new government, THE CANADA PRESS (Mar. 20, 2013), LEXIS (accessed Oct. 20, 2013).

205. As that term is used in the United States.

206. Spain's new government to legalize gay marriage, REUTERS (Apr. 15, 2004), http://www.webcitation.org/5kV80Iu9U.

207. Filipe Rufino, Portuguese socialists win absolute majority, EU OBSERVER (Feb. 21, 2005), http://archive.is/IwhEu.

208. His Socialist party lost its absolute majority in the 2009 election; but it is hard to blame this on his announced intention to pursue same-sex marriage, since the economic situation deteriorated following the 2008 economic crisis and the "Left Bloc," a left wing party which gained additional seats in Parliament, was also favorable to same sex marriage. 
There was little public backlash to legalization, notably because Portugal's history of oppressive dictators has left it a socially progressive country in terms of human rights. ${ }^{209}$ Moreover, it should be recalled that since 2001 Portuguese law provided for recognition of de facto couples, "whatever their sex" 210 and since 2004 the Constitution explicitly prohibited discrimination based on sexual orientation. Lastly, the fact that neighbor Spain had already legalized same-sex marriage made it easier for Portugal to follow suit.

Additionally, the United Kingdom, under the leadership of David Cameron, has legalized same-sex marriage in spite of having a center-right government (a majority coalition led by the Conservative Party). However, Cameron is much more liberal (as that term is used in the United States) than a typical member of his party. He has thus been able to attract LGBT voters to the Conservative Party (with 30 percent of the gay community saying before the last election they would vote for the Conservative party, compared to 27 percent who would vote for Liberal Democrats and 38 percent who would vote for Labour). ${ }^{211}$

In Germany, however, gay rights advocates have good cause to be skeptical of a center-right party's willingness to grant marriage equality rights. While Chancellor Merkel's party has made some noise about increasing the rights given to domestic partnerships, ultimately Merkel decided that her party would continue to oppose any additional granting of rights to same-sex couples. ${ }^{212}$

Progressive socialist parties can be elected even in some very religious nations because religiosity does not necessarily determine people's votes. While it is relevant to voting behavior in many countries, its influence is weakening. Kerman Calvo et al. explain, "Religiosity is surely lessening its political significance and has consequently much lower impact on voting. Party leaders, building strategically on the outcomes of secularisation and social change processes, as well as on increasing levels of education and information, have decided to maximise their electoral appeals by downplaying the conflictive ladders of religious divisions." 213 A regression performed by Calvo et al., for example, finds that religiosity has much less influence on voting behavior in Portugal than in Spain. ${ }^{214}$ This might serve to explain why Portugal's

209. Frank Bruni, One Country's Big Gay Leap, N. Y. TiMES, Oct. 8, 2011, at SR-3.

210. Lei No. 7/2001, de 11 de Maio 2001, Adopta medidas de protecçāo das uniões de facto [Law 7/2001, of May 11, 2001, Protection measures of unmarried couples], DIÁRIO DA REPÚBLICA Série I-A, No. 109, de 11.05.2001, p. 2797 (Port.) available at http://dre.pt/pdf1sdip/ 2001/05/109A00/27972798.pdf.

211. Marc Shoffman, Cameron in the pink: Tory leader sees increased support in the gay community, PINK News (Apr. 17, 2006), http://archive.is/Idyz8.

212. Laura Stevens, Merkel Scraps Gay Rights Push, Wall St. J., Mar. 5, 2013, at A10. Although this may change, depending on whether Merkel must compromise in order to form a coalition with the SPD.

213. Kerman Calvo, Álvaro Martínez, \& José Ramón Montero, Eadem sed Aliter: Religious Voting in Portugal and Spain (Feb. 2006), http://www.upf.edu/dcpis/_pdf/jrmontero.pdf.

214. Id. ("In sharp contrast [to Spain], a quick perusal at the results of Table 7 confirms that, in contemporary Portugal, religiosity continues to be a weak predictor of the vote."). 
government could pass same-sex marriage with little backlash, in spite of Portugal being a deeply religious country.

Thus, in Europe, religiosity is not as strong a predictor of state policy as in the United States because Europeans are less likely to resort to popular votes to determine whether to legalize same-sex marriage and because religiosity in Europe does not correlate as strongly to voting behavior. Thus, European legislatures, more than their American counterparts, are free to ignore public attitudes and either legalize same-sex marriage, in spite of low public support (such as in Portugal), or refuse to legalize in spite of strong public support (such as in Germany).

However, religiosity remains an important factor, particularly in Western Europe, and over time, Western Europe should be expected to influence Eastern Europe, at least for those countries in Eastern Europe that are members of the EU. Some people even argue that there is currently a movement in the EU towards total religious neutrality. ${ }^{215}$ For example, last year, when Slovakia attempted to print Christian symbols on Euro coins, it was blocked from doing so by the European Commission, before the latter finally gave in. ${ }^{216}$ The charge against Slovakia's attempt to print religious Euro coins was led by France, which "enforces a rigid division of church and state at home." 217 As Western Europe continues to influence the Eastern European members of the EU towards secularization, and as the societies of these latter countries develop and modernize, one would expect religiosity to become less influential in those countries' politics, opening room for change on issues involving the rights of same-sex couples.

\section{CONCLUSION}

We have found three main trends in the United States and Europe regarding the relationship between religiosity and support for same-sex marriage. First, in the United States, there is a remarkably close correlation between religiosity and the legal status of same-sex marriage. The states that have legalized same-sex marriage or openly recognize same-sex relationships tend to be the least religious, while the states that have constitutional bans on same-sex marriage tend to be the most religious. Second, in Western Europe, there is a close correlation between religiosity and the legal status of same-sex marriage. Where the correlation does not hold, at least in some cases (such as Spain and Germany), it is a product of which party is in control of the government. Centerright parties tend to slow reform in non-religious countries, whereas center-left parties tend to expedite reform in more religious countries. Third, Eastern

215. Andrew Higgins, A More Secular Europe, Divided by the Cross, N.Y. TIMES, June 17, 2013, at A-1.

216. Id.

217. Id. 
Europe is different from the United States and Western Europe in that low religiosity there does not translate into same-sex marriage legalization. We suspect the reason this correlation disappears in Eastern Europe is because of the legacy of communism, which often involved enforced atheism. Thus, part of Eastern Europe is very non-religious, but also politically and culturally conservative. The two big exceptions in Eastern Europe which have provided recognition to same-sex relationships, are the Czech Republic and Hungary both of which are the closest to the West both culturally and geographically and both of which had the biggest revolts against communism (in 1968 and 1956, respectively). Thus, religiosity is one explanatory factor that can be extremely useful in predicting same-sex marriage support in both the United States and Western Europe. And at least in the European Union, Western Europe should be expected to influence Eastern Europe over time. ${ }^{218}$

218. Although outside the EU, such as in former Soviet Bloc countries, the influence of Western Europe is quite limited. 